\title{
The Bioprospecting of Anti-Vibrio Streptomyces species: Prevalence and Applications
}

\author{
Loh Teng-Hern Tan ${ }^{1,2}$, Learn-Han Lee ${ }^{1,4^{*}}$, Bey-Hing Goh G.4* $^{3, H}$ \\ ${ }^{1}$ Novel Bacteria and Drug Discovery (NBDD) Research Group, Microbiome and Bioresource Research Strength Jeffrey \\ Cheah School of Medicine and Health Sciences, Monash University Malaysia, 47500 Bandar Sunway, Selangor Darul \\ Ehsan, Malaysia. \\ ${ }_{2}^{2}$ Institute of Biomedical and Pharmaceutical Sciences, Guangdong University of Technology, Guangzhou 510006, PR China. \\ ${ }^{3}$ Biofunctional Molecule Exploratory (BMEX) Research Group, School of Pharmacy, Monash University Malaysia, 47500 \\ Bandar Sunway, Selangor Darul Ehsan, Malaysia. \\ ${ }^{4}$ Health and Well-being Cluster, Global Asia in the 21st Century (GA21) Platform, Monash University Malaysia, Bandar \\ Sunway 47500, Selangor, Malaysia
}

\begin{abstract}
Vibrio sp. has been a major pathogen that resulted in difficult to treat infections, and greatly impacting the aquaculture industry. Thus, more effective approaches are needed to overcome this problem. Bacteria of the genus Streptomyces is a group of prolific producers for various bioactive compounds. Streptomyces species with antibacterial activity against Vibrio sp. have been reported from numerous studies, indicating that Streptomyces could be a good candidate for treatment of Vibrio infections. This review aims to provide an overview on the distribution of the Streptomyces with anti-Vibrio activity from diverse geographical locations. Furthermore, this review also highlighted that Streptomyces sp. can be a great source for anti-Vibrio agents to control vibriosis, such as in the aquaculture settings.
\end{abstract}

Keywords: Streptomyces, Vibrio sp., secondary metabolites, antibacterial, biocontrol agent

Received: $18^{\text {th }}$ May 2019

Accepted: $15^{\text {th }}$ June 2019

Publish Online: $05^{\text {th }}$ July 2019
Correspondence: Bey-Hing Goh, goh.bey.hing@ monash.edu. School of Pharmacy; Learn-Han Lee, lee. learn.han@monash.edu, leelearnhan@yahoo.com. Jeffrey Cheah School of Medicine and Health Sciences, Monash University Malaysia, 47500 Bandar Sunway, Selangor Darul Ehsan, Malaysia.

Citation: Tan LTH, Lee LH, Goh BH, The bioprospecting of anti-Vibrio Streptomyces species: prevalence and applications. Prog Microbes Mol Biol 2019; 2(1): a0000034

\section{INTRODUCTION}

Seafood is rich in nutritional values, serving as a healthy food choice for major protein source in human diet. For the past decades, the accelerated growth in commercial aquaculture for total seafood supply is growing in folds in order to satisfy the increased demand for seafood globally ${ }^{[1]}$. However, seafood is prone to various contaminants, such as pathogenic microorganisms which include bacteria, viruses, fungi and parasites ${ }^{[2-7]}$. These pathogens are posing high risk for seafood and water borne illnesses in consumers ${ }^{[8-11]}$. This is because seafood can be a vehicle for pathogens. Vibrio sp., which is one of the genera from Bacteria kingdom ${ }^{[12]}$, has been associated with gastroenteritis and wound infections in human ${ }^{[13]}$, such as $V$. vulnificus $^{[14]}, V$. parahaemolyticus ${ }^{[15]}$ and $V$. cholerae ${ }^{[16]}$. Foodborne Diseases Active Surveillance Network (FoodNet) reported that in the year 2018, Vibrio sp. have inflicted 537 cases of infections with 1.1 incidence per 100,000 population in United States. FoodNet also indicated that the number of Vibrio infection cases have increased sig- nificantly by $109 \%$ in 2018 when compared with previous reported cases within the year 2015 to $2017^{[17]}$. Furthermore, Vibrio sp. have also inflicted several major outbreaks worldwide ${ }^{[18-20]}$. For instance, the biggest outbreak of cholera was reported in Haiti on October 2010 with more than seven thousand deaths recorded for the first time in more than a century ${ }^{[21]}$.

Besides causing infections in human, Vibrio species is also a great threat towards aquaculture by causing vibriosis that hampers the fishery industry growth and causes serious economic losses globally. The etiological agents of vibriosis include $V$. harveyi, $V$. alginolyticus, V. anguillarum, V. salmonicida, V. mimicus and V. parahaemolyticus ${ }^{[22]}$. These pathogens have been reported to cause mortalities up to $100 \%$ in aquaculture. For example, the $V$. harveyi has caused mass mortality of black tiger shrimp Penaeus monodon by causing luminous vibriosis ${ }^{[23-25]}$. Another species $V$. mimicus is also responsible for epidemic in catfishes in China with high mortality rate between 80 to $100 \%{ }^{[26]}$. Consequently, 
antibiotics are used as prophylactic measures or to treat the established infections in the culture systems due to the immense impact of vibriosis in aquaculture. However, antibiotic resistant strain of pathogens are emerging due to the routine and uncontrolled usage of antibiotics and leading to therapeutic failure of existing antibiotic ${ }^{[27]}$. Therefore, it necessitates the search for more effective alternatives to overcome this problem. In this regards, recent efforts have been evidenced in bioprospecting for natural products derived from plant ${ }^{[28-32]}$, animal ${ }^{[33]}$ or microbial origins ${ }^{[34]}$ with promising antimicrobial effects to facilitate future development of new strategies against the antibiotic resistant strains of Vibrio.

The interest on the discovery of bioactive compounds from microbial origin is increasingly attractive towards the researchers, especially from the extreme environments. This is because that the sea and soil microbiota are frequently exposed to the complex, fluctuating and competitive environments which is believed to be the driving forces for metabolic pathway adaptation and lead to production of valuable metabolites ${ }^{[35-39]}$. The extremely diverse and unsurpassed richness of the secondary metabolism exhibited by Streptomyces has made these filamentous bacteria to serve as a rich bioresource for valuable bioactive compounds ${ }^{[35,40-43]}$. Ever since the discovery of streptomycin as the first therapeutically beneficial antibiotic in $1944^{[44]}$, Streptomyces species have been known to synthesize enormous amount of bioactive secondary metabolites, including antibiotics, antitumor agents, antiparasitic, immunosuppressive agents and industrially important enzymes ${ }^{[34,45,46]}$. The genus Streptomyces is ubiquitously found in soil. In fact, they are also found to inhabit in wide range of niches such as in the aquatic environments, marine dwelling animals ${ }^{[47]}$ and as symbionts of plants ${ }^{[48]}$ and insects ${ }^{[49]}$. Therefore, we attempted to evaluate the potential of Streptomyces as a source of antibiotics against the antibiotic-resistant strains of Vibrio. This review discusses the current knowledge on the Streptomyces as a promising biocontrol agent of Vibrio and assesses their distribution, isolation, secondary metabolites production. Figure 1 depicts the potential of Streptomyces bacteria as a source for anti-Vibrio metabolites and their application in aquaculture.

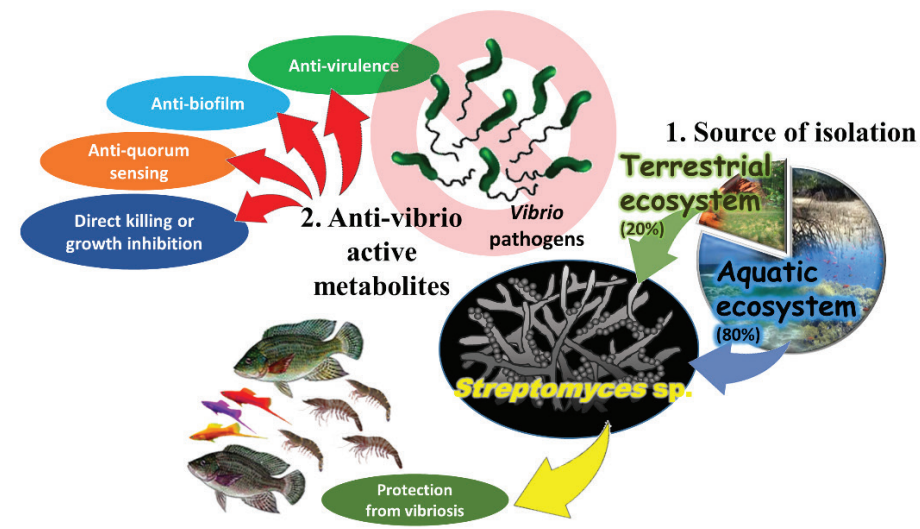

3. Application in aquaculture

Figure 1. The summary of the potential of Streptomyces bacteria as a source for anti-vibrio biocontrol agent and its application as probiotic in aquaculture. 1. Streptomyces sp. has been isolated from different ecosystems, including both terrestrial and aquatic environments. The percentage on the pie chart illustrates the proportion of Streptomyces strain with anti-Vibrio activity from respective ecosystem. (Percentage of isolation from specific sources from both ecosystems are provided in the text) 2 . The anti-Vibrio active metabolites produced not only exhibits direct killing or growth inhibitory effect against Vibrio pathogens, specific mechanisms are also demonstrated such as anti-virulence, anti-biofilm and anti-quorum sensing activity against Vibrio pathogens. 3. Streptomyces also exhibits the potential to be used as biocontrol agent in aquaculture for prevention of vibriosis.

\section{VIBRIO sp. AND VIRULENCE FACTORS}

Being one of the six genera for the family Vibrionace$a e$, the genus Vibrio are Gram-negative, halophilic and curved-rod in shape ${ }^{[50]}$. They are ubiquitous inhabitants of the warm coastal and estuarine waters as well as in the gut of filter-feeding shellfish. There are at least 12 species of Vibrio have been known to be pathogenic and cause foodborne diseases in human ${ }^{[51]}$. Besides capable to cause massive pandemics resulting in many cases of infections and deaths worldwide, some of the Vibrios are known to be pathogenic to aquatic organisms, such as finfish, shellfish and corals ${ }^{[52]}$.

Virulence factors are the unique molecular features possessed by pathogen for colonisation, nutrient acquisition, infection and damage to a host ${ }^{[53]}$. Studies have identified numerous virulence factors from the genus $V i b$ rio, including pathogenic $V$. cholerae, $V$. parahaemolyticus and $V$. vulnificus. For example, the cholera toxin (CTX), a well-known virulence factor or enterotoxin produced by $V$. cholerae ${ }^{[54]}$, the thermostable direct hemolysin $(t d h)$ and the $t d h$-related hemolysin (trh) in $V$. parahaemolyticus ${ }^{[15]}$ and capsule polysaccharide (CPS) in $V$. vulnificus ${ }^{[55]}$. All these virulence factors are attached on the surface of the cells or are secreted into the extracellular environment. To transport these virulence factors, specific secretion system is essential to facilitate the delivery of the effector virulence factors into host cells from the bacterial cells. For instance, the type III secretion systems (T3SS1 and T3SS2) are the well characterized systems play significant roles in the pathogenicity of Vibrio pathogens. Studies demonstrated that regulation of virulence gene expression could be the 
critical aspect for pathogenicity. To illustrate, a higher expression of those virulence genes could render a bacterial strain to be virulent, but this may not often be the case. As pathogenicity of bacteria is not always dependent on the presence of virulence genes ${ }^{[58]}$. Quorum sensing (QS) is a machinery adapted by bacteria to coordinate the expression of certain genes, including those encoding virulent phenotypes, through the mediation of small signalling molecules [56]. For examples, the $N$-acylhomoserine lactone and the multi-channel QS systems are the two common QS systems acquired by the Vibrio bacteria ${ }^{[57,58]}$

There are many strategies used to control Vibrio infections, including the antibiotics, water disinfectants, vaccines, immunostimulants, bacteriophages and probiotics in aquaculture ${ }^{[59-61]}$. Despite that, new antibiotics or chemotherapeutic approaches are needed to cope with the ever-increasing evidences of antibiotic resistance among the Vibrio sp. Besides that, inhibition of the virulence factors of the pathogens is an alternative to kill the Vibrio pathogens such as the disruption of bacterial cell-to-cell signalling or quorum sensing and the development of antagonistic compounds (antivirulence therapy) that specific targeting the virulence machinery of Vibrio pathogens. Hence, it is important to fully understand the virulence regulation mechanism (described earlier) in order to identify better therapeutic targets for prevention of outbreaks caused by Vibrio pathogens. In this review, Streptomyces bacteria is suggested as the promising candidate for the management of Vibrio pathogens based on the potential of Streptomyces bacteria in the production of anti-Vibrio compounds and its application in aquaculture.

\section{EMERGENCE OF ANTIBIOTIC RESISTANT VIBRIO sp.}

Given the excessive use of antibiotics for the past few decades, the emergence and the ever-increasing prevalence of antimicrobial resistant pathogens is of a great concern in global health ${ }^{[27,62-64]}$. Today, many of antibiotics have been totally restricted in agriculture and aquaculture of developed countries due to the enormous detrimental impacts on the environment ${ }^{[65,66]}$. Despite that, the unrestricted use of antibiotics remains in countries with growing scale of agriculture and aquaculture industries such as China, Chile and Thailand. The antibiotics were used prophylactically by most of the farmers from aquaculture and agriculture settings to prevent or treat disease outbreaks, particularly infections caused by Vibrio bacteria. For instance, excessive and frequent use of antibiotics as preventive management was observed from shrimp farming in Thailand ${ }^{[62]}$. A total of $86 \%$ of the shrimp farmers from Thailand were reported highly dependent on antibiotic use as a preventive measure, $14 \%$ of the farms even used antibiotics in a daily basis. Norfloxacin, oxytetracycline, enrofloxacin and sulphonamides were the commonly used antibiotics in shrimp farms ${ }^{[62]}$. Frequent use of antibiotic is also widely evident in other regions, including Mexico ${ }^{[67]}$, Italy ${ }^{[27]}$, Philippines ${ }^{[68]}$ and China ${ }^{[69]}$.

Undoubtedly, the enormous misuse of antibiotics has resulted the ever-increasing reports of multi-drug resistant Vibrio species in aquaculture settings and marine environments ${ }^{[70]}$. For instance, a recent study showed the presence of Vibrio sp. resistant to $\beta$-lactam and tetracycline in the hemolymph of Litopenaeus vannamei shrimp ${ }^{[71]}$. Furthermore, a plasmid mediated tetracycline resistant $V$. parahaemolyticus was isolated from shrimps infected with acute hepatopancreatic necrosis disease (AHPND), indicating the presence of antibiotic resistance that can potentially be transferred through transposition, conjugation and plasmid uptake to other bacterial species in the same environment ${ }^{[72]}$. The disease AHPND, also known as early mortality syndrome, is one of the major threats to shrimp farming. The disease has caused severe mortality up to $100 \%$ in aquaculture of $P$. vannamei and P. monodon ${ }^{[73,74]}$. Recently, Castillo et al. (2015) ${ }^{[75]}$ reported a draft genome sequence of $V$. parahaemolyticus strain VH3 isolated from farmed amberjack in Greece. The strain VH3 was found to possess multidrug resistance efflux pumps and antibiotic resistant genes for fluoroquinolones and tetracycline ${ }^{[75]}$. Moreover, $V$. parahaemolyticus has also been reported to be resistant to numerous classes of antibiotics such as penicillins (ampicillin), aminoglycosides (amikacin, kanamycin, streptomycin), cephalosporins (cefotaxime, ceftazidime, cefazolin) ${ }^{[76,77]}$, quinolones (ciprofloxacin, nalidixic acid), macrolides (azithromycin, erythromycin) and chloramphenicol ${ }^{[78,79]}$.

Besides the antibiotic resistance incidences occur in aquaculture, there are enormous number of literatures focus on the antibiotic resistance of $V$. cholerae ${ }^{[80,81]}$, the causative agent of cholera which is an infectious diarrheal disease associated with hypovolemic shock and rice watery stools. This bacterium appears to be a reemerging problem to human worldwide, causing many disease outbreaks in which constant monitoring for their ever-changing antibiotic resistance profile is required. Over the years, multidrug resistant $V$. cholerae has been reported from many regions of the world especially the under-developed and developing countries, including Bangladesh [ ${ }^{[82]}$, India ${ }^{[83]}$, Africa ${ }^{[84]}$, Haiti ${ }^{[85]}$ and Vietnam ${ }^{[86]}$. Reports have shown that clinical isolates of $V$. cholerae have become resistant to numerous antibiotics including tetracycline ${ }^{[87]}$, ampicillin ${ }^{[88]}$, nalidixic acid

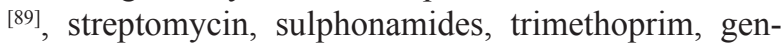
tamicin ${ }^{[90]}$ and ciprofloxacin ${ }^{[89]}$. V. cholerae is a naturally competent bacterium containing a highly diverse genome (genomic plasticity), readily taking up external DNA and possibly recombine into their genome [91]. The antibiotic resistance in $V$. cholerae was attributed to target modification or acquisition of resistance gene cassettes from mobile genetic elements (MGE). Both integrative conjugative elements (ICE) and superintegron are known to be the major source of conferring antibiotic resistance in $V$. cholerae. For instance, the SXT element, an ICE responsible for gene translocation, is found in $V$. cholerae encoding various antibiotic resistance genes such as chloramphenicol, sulphamethoxazole, trimethoprim and streptomycin ${ }^{[92]}$. In fact, these SXT and closely-related elements are present in almost all $V$. cholerae clinical isolates and some environmental isolates from Asia and Africa ${ }^{[93]}$. A group of researcher has confirmed that the SXT elements were the vectors of genes conferring multidrug resistance in Chinese epidemic $\mathrm{O} 1 \mathrm{~V}$. cholerae to tetracycline and trimethoprimsulfamethoxazole [94]. Taken together, the resistance development limits the useful lifespan of antibiotic and 
results in the requirement for a constant introduction of new antibacterial compounds ${ }^{[95,96]}$.

\section{STREPTOMYCES sp. AS POTENTIAL SOURCE FOR ANTI-VIBRIO AGENT}

The genus Streptomyces (phylum: Actinobacteria) are soildwelling Gram-positive bacteria with high G+C (70\%) genomic content. They have characterized filamentous growth involving tip extension and filamentous branching which eventually form network of filaments named as substrate mycelium ${ }^{[97,}{ }^{98]}$. Interestingly, Streptomyces possess a remarkably complex developmental cycle ${ }^{[99]}$. Under environmental stress and solid cultivation condition, they are capable to switch from vegetative phase (substrate mycelium) into a reproductive sporulation phase (aerial hyphae mycelium) ${ }^{[100]}$. The secondary metabolites are produced at the end of the active vegetative growth and during the dormant or reproduction stage ${ }^{[101]}$. More than 70 years ago, streptomycin was discovered as the first therapeutically beneficial antibiotic produced by $S$. griseus ${ }^{[44]}$. Today, Streptomyces bacteria remain to be prolific sources of novel secondary metabolites with diverse range of biological activities such as antibacterial, antitumor, antiviral, antifungal, immunosuppressive activity, antifeedant, insecticidal and neuroprotective activity ${ }^{[45,102]}$. Numerous studies have also described the production of valuable enzymes and compounds by Streptomyces with industrially and clinically importance ${ }^{[45,103,104]}$.

The enormous biosynthetic capabilities of Streptomyces have made them an irreplaceable resource for microbial natural products in microbial world ${ }^{[105]}$. The Streptomyces derived secondary metabolites are structurally diverse and based on different backbone structures, including polyketides, $\beta$-lactams, peptides and pyrroles ${ }^{[42,101]}$. For example, the bioactive compounds include glycopeptides (vancomycin, teicoplanin, telavancin) ${ }^{[106]}$, angucycline (tetrangomycin, landomycin, urdamycin) ${ }^{[107]}$, tetracycline (chlortetracycline, oxytetracylcine, demeclocycline) ${ }^{[108]}$, phenazine (saphenamycin, endophenazine, phenazinomycin) ${ }^{[109]}$, macrolide (erythromycin, spiramycin, oleandomycin) [110], aminoglycoside (streptomycin, kanamycin, tobramycin) ${ }^{[11]}$, benzoxazolophenanthridine (jadomycin) ${ }^{[112]}$ and oligosaccharides (flambamycin, avilamycin, curamycin) ${ }^{[113]}$.

Majority of the Streptomyces derived secondary metabolites are known to be antibiotics, given that they are needed for inhibiting the growth of other competing microorganisms present in the same environment ${ }^{[114]}$. The production of secondary metabolites also involves in the symbiotic interactions between the Streptomyces and the plants. There are strains of saprophytic Streptomyces colonize the plant roots and even in the plant tissues. The antibiotics produced by Streptomyces protect the host plant from potential pathogens while the symbionts provide nutrients for Streptomyces development ${ }^{[48]}$. Terrestrial soils are the classical habitats of Streptomyces sp. but current evidences indicate that Streptomyces can be isolated from marine soils as well [42,115]. These soils are known to be complex environments with many stressors such as diverse and variable nutrient availability, huge fluctuation in temperature, $\mathrm{pH}$ and salinity ${ }^{[116]}$. As a group of non-motile microorganism, Strepto- myces species requires to evolve and adapt for the survival in the diverse environmental challenges. Bentley et al. (2002) ${ }^{[117]}$ explained the large genome (>8Mbp) of Streptomyces sp. that encoding regulators, transport proteins and enzymes render them to be resistant to those environmental stressors. In 2001, Streptomyces coelicolor A3(2) was reported to possess a more than 8 Mega base pairs linear chromosome as the first and largest ever sequenced microbial genome ${ }^{[117]}$. A large proportion of the genome was shown to contain regulatory genes which are likely to be involved in detection of, and response to extracellular stimuli and stresses ${ }^{[117]}$. Furthermore, approximate 23 cluster of the genes consisted of $4.5 \%$ of the total genome were found to be encoded for the biosynthetic enzymes that produce wide range of secondary metabolites. Ikeda et al. $(2003)^{[118]}$ further revealed a larger secondary metabolic gene cluster covering approximately $6 \%$ of the genome found in S. avermitilis ATCC31267. The genome of Streptomyces is significantly larger as compared to the recent reported 5.1 Mega base pairs chromosome from the genus Bacillus. Also as one of the best characterized bacterial genera, the genus Bacillus has been extensively exploited for biotechnological use in the food and pharmaceutical production ${ }^{[119]}$. In the light of the expanding knowledge of microbial genetics and genomics, genome mining has revealed the potential of Streptomyces sp. in synthesizing a large diversity of compounds that have yet to be identified via the detection of numerous cryptic novel secondary metabolite biosynthetic gene clusters ${ }^{[120,121]}$. Overall, these interesting features of Streptomyces have demonstrated that this genus is a very good candidate for bioprospection of bioactive compounds with antibacterial properties ${ }^{[122]}$, especially in anti-Vibrio activity as the main focus of this review.

\section{STUDIES OF STREPTOMYCES WITH ANTI- VIBRIO ACTIVITY}

Up to the year 2015, based on the data reported from 64 studies (Table 1), there are around 128 strains of Streptomyces exhibited antibacterial activity toward Vibrio sp. Two and 3 strains of Streptomyces were shown to exhibit antivirulence and antibiofilm activity against Vibrio sp., respectively. Table 1 tabulates the number of Streptomyces strains with anti-Vibrio activity with different stages of work performed ranging from the preliminary screening stage to an in-depth characterization of a Streptomyces strain exhibiting anti-Vibrio activity. Based on these studies, Streptomyces strains with anti-Vibrio activities have been isolated from diverse ecosystems ranging from terrestrial to marine environments, and from marine organisms to aquatic plants. As depicted in Table 1, $80 \%$ of the studies revealed Streptomyces strains with anti-Vibrio activities were isolated from aquatic environments while the remaining $20 \%$ of the studies showed Streptomyces with anti-Vibrio activities were derived from terrestrial origin. Majority of the studies $(48.3 \%)$ isolated Streptomyces with anti-Vibrio activity from marine and mangrove sediment, followed by marine organisms such as sponges, coral and fishes $(21.7 \%)$, terrestrial soils (18.3\%), aquatic plants (6.7\%), water $(3.3 \%)$ and terrestrial plants $(1.7 \%)$. Among the 128 strains of Streptomyces with antibacterial activity 
against Vibrio sp., 116 strains (90\%) were isolated from aquatic environment. This data suggests that marine ecosystem could be more preferable source for isolation of Streptomyces with anti-Vibrio activity as compared to the samples collected from terrestrial regions. Despite that, it cannot be disregarded that terrestrial soil could be a potential source for Streptomyces strains with anti-Vibrio activity. In fact, some interesting Streptomyces strains with anti-Vibrio activity were reported from terrestrial soils ${ }^{[123,}{ }^{124]}$.

Table 1. Different isolation sources of Streptomyces with anti-Vibrio activity.

\begin{tabular}{|c|c|c|c|c|c|}
\hline $\begin{array}{l}\text { Source of } \\
\text { isolation }\end{array}$ & Country & Locations & $\begin{array}{l}\text { Number of } \\
\text { Streptomyces } \\
\text { with anti-Vibrio } \\
\text { activity isolated }\end{array}$ & The identified Streptomyces sp. with anti-Vibrio activity & References \\
\hline \multirow[t]{23}{*}{$\begin{array}{l}\text { Marine } \\
\text { sediment }\end{array}$} & India & Andaman Island & 6 & $\begin{array}{l}\text { Streptomyces sp. MKS-09 (S. xantholiticus) } \\
\text { Streptomyces sp. MKS-13 (S. aureofascicus) } \\
\text { Streptomyces sp. MKS-17 (S. galtieri) } \\
\text { Streptomyces sp. MKS-24 (S. vastus) } \\
\text { Streptomyces sp. MKS-35 (S. galbus) } \\
\text { Streptomyces sp. MKS-39 (S. rimosus) }\end{array}$ & [125] \\
\hline & & Sediment from coastal area of & 1 & Streptomyces sp. S8-08 (S. albus DQ333301.1 99\%) & [126] \\
\hline & & $\begin{array}{l}\text { Thondi, Palk Bay (Lat. 945'N, Long. } 79 \\
{ }^{\circ} 3^{\prime} E \text { ) }\end{array}$ & & & \\
\hline & & Chennai coast area, Tamilnadu & 1 & Streptomyces ECR3 & [127] \\
\hline & & Vellar Estuary, Tamilnadu & 3 & $\begin{array}{l}\text { Streptomyces sp. F1 } \\
\text { Streptomyces sp. F2 } \\
\text { Streptomyces sp. F3 }\end{array}$ & [128] \\
\hline & & ns & 1 & Streptomyces sp. isolate 6 & [129] \\
\hline & & $\begin{array}{l}\text { Royapuram, Muttukadu, Mahabalipuram } \\
\text { seashores, Adyar estuary }\end{array}$ & 2 & $\begin{array}{l}\text { Streptomyces sp. C11 } \\
\text { Streptomyces sp. C12 }\end{array}$ & [130] \\
\hline & & $\begin{array}{l}\text { Near-sea shore sediment from Palk bay, (Lat. } \\
9^{\circ} 44^{\prime} 10^{\prime \prime} \mathrm{N} \text {, Long. } 79^{\circ} 10^{\prime} 45^{\prime} \mathrm{E} \text { ) Southeast } \\
\text { coast of Thondi, Tamilnadu }\end{array}$ & 1 & Streptomyces sp. (99\% S. fradiae BDMS1) & [131] \\
\hline & & Visakhapatnam, India & 1 & Streptomyces sp. KS1908 & [132] \\
\hline & & $\begin{array}{l}\text { Andaman and Nicobar Islands (11 } 38^{\prime} 42.8^{\prime \prime}, \\
\left.92^{\circ} 42^{\prime} 30.7^{\prime \prime}\right)\end{array}$ & 5 & $\begin{array}{l}\text { Streptomyces sp. NIOT-VKKMA02 }(100 \% \text { S. griseus }) \\
\text { Streptomyces } \mathrm{sp} \text {. NIOT-VKKMA26 }(100 \% \text { S. venezuelae })\end{array}$ & [133] \\
\hline & & Bay of Bengal & 1 & Streptomyces sp. LCJ94 & [134] \\
\hline & & $\begin{array}{l}\text { Bay of Bengal (Lat. 11 }{ }^{\circ} 42^{\prime} 23.15^{\prime}{ }^{\prime} \mathrm{N}, \text { Long. } \\
\left.79^{\circ} 46^{\prime} 57.97^{\prime} \mathrm{E}\right)\end{array}$ & 1 & Streptomyces sp. SS7 & [135] \\
\hline & & Saltpan soil sample from & 1 & Streptomyces sp. DPTD215 (98\% S. noursei AY999827) & [136] \\
\hline & & $\begin{array}{l}\text { Parangipettai Potnovo (Lat. 11³0’N, Long. } \\
79^{\circ} 46^{\prime} \text { E) Cuddalore district, Tamilnadu }\end{array}$ & & & \\
\hline & & $\begin{array}{l}\text { Versova coast, Mumbai (Lat. } 19 \\
{ }^{2} 28^{\prime} 26.32^{\prime \prime} N \text {, Long. } 72^{\circ} 48^{\prime} 07.21 \text { 'E) }\end{array}$ & 1 & Streptomyces sp. MVCS6 (KC292198) & [137] \\
\hline & & $\begin{array}{l}\text { Versova coast, Mumbai (Lat. } \\
19^{\circ} 08 ' 26.12 \text { 'N, Long. } 72^{\circ} 48^{\prime} 07.41 \text { 'E) }\end{array}$ & 1 & Streptomyces sp. MVSC13 (KC292199) & [138] \\
\hline & China & Submarine sediment from & 1 & Streptomyces sp. SCSIO 01689 (98.3\% S. sanyensis) & [139] \\
\hline & & $\begin{array}{l}\text { Sanya Bay }\left(109^{\circ} 32^{\prime} \mathrm{E}, 18^{\circ} 11^{\prime} \mathrm{N}\right) \text {, northern } \\
\text { South China sea }\end{array}$ & & & \\
\hline & & $\begin{array}{l}\text { Sediment from shrimp farms Hainan Island, } \\
\text { China Marine }\end{array}$ & 7 & $\begin{array}{l}\text { Streptomyces sp. A03, A05 (S. cinerogriseus - majority antagonistic } \\
\text { to Vibrio } \mathrm{sp} .) \\
\text { Streptomyces } \mathrm{sp} . \mathrm{A} 26, \mathrm{~A} 42 \text { (S. griseorubroviolaceus) } \\
\text { Streptomyces } \mathrm{sp} . \mathrm{A} 41 \text { (S. lavendulae) } \\
\text { Streptomyces } \mathrm{sp} . \mathrm{A} 45 \text { (S. roseosporus) } \\
\text { Streptomyces } \mathrm{sp} . \mathrm{B} 15 \text { (S. griseofuscus) }\end{array}$ & [140] \\
\hline & $\begin{array}{l}\text { Viet- } \\
\text { nam }\end{array}$ & $\begin{array}{l}\text { Sediment from shrimp culture pond in Thua } \\
\text { Thien Hue }\end{array}$ & 1 & Streptomyces sp. A1 HM854225 & {$[141,142]$} \\
\hline & Korea & $\begin{array}{l}\text { Seaweed rhizosphere and sediment }(10 \mathrm{~m} \\
\text { depth) from coast of Korea }\end{array}$ & 1 & Streptomyces sp. PK288-21 (99\% S. atrovirens DQ026672.1) & [143] \\
\hline & Egypt & $\begin{array}{l}\text { Coastal lagoon sediment from Sinai } \\
\text { Peninsula }\end{array}$ & 1 & S. ruber ERKH2 & [144] \\
\hline & Cuba & Near-shore sediment from & 3 & & [145] \\
\hline
\end{tabular}




\begin{tabular}{|c|c|c|c|c|c|}
\hline & $\begin{array}{l}\text { Austra- } \\
\text { lia }\end{array}$ & $\begin{array}{l}\text { Queensland, (Lat. 2143'09'S, Long. } \\
149^{\circ} 25^{\prime} 54^{\prime} \text { 'E) }\end{array}$ & 3 & $\begin{array}{l}\text { Streptomyces sp. CLS- } 28 \\
\text { Streptomyces sp. CLS-39 } \\
\text { Streptomyces sp. CLS- } 45\end{array}$ & [146] \\
\hline \multirow{5}{*}{$\begin{array}{l}\text { Man- } \\
\text { grove } \\
\text { sediment/ } \\
\text { rhizo- } \\
\text { phere } \\
\text { soil/es- } \\
\text { tuarines }\end{array}$} & \multirow[t]{5}{*}{ India } & $\begin{array}{l}\text { Mangalavana, Narakkal, Puthuvyppu, } \\
\left(9^{\circ} 55^{\prime} 10^{\circ} 10^{\prime} \mathrm{N} \text { and } 76^{\circ} 10-76^{\circ} 20^{\prime} \mathrm{E}\right.\end{array}$ & ns & ns & {$[147]$} \\
\hline & & Sundarbans, India and Bangladesh & ns & ns & {$[148]$} \\
\hline & & $\begin{array}{l}\text { Velar estury, Tamilnadu, India (lat. } \\
11.4900^{\circ} \mathrm{N} \text { Long. } 79.7600^{\circ} \mathrm{E} \text { ) }\end{array}$ & 1 & Streptomyces sp. MA7 & {$[149]$} \\
\hline & & $\begin{array}{l}\text { East coast region, Pichavaram mangrove } \\
\text { forest }\left(\text { Lat. } 11.43^{\circ} \mathrm{N} \text {, Long. } 79.77^{\circ} \mathrm{E}\right) \text { Tam- } \\
\text { ilnadu, India }\end{array}$ & 2 & $\begin{array}{l}\text { Streptomyces sp. ECR64 } \\
\text { Streptomyces sp. ECR77 (accession number KF158225) (S. labe- } \\
\text { dae) }\end{array}$ & [150-152] \\
\hline & & 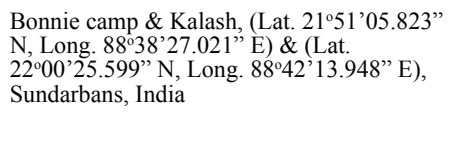 & 3 & 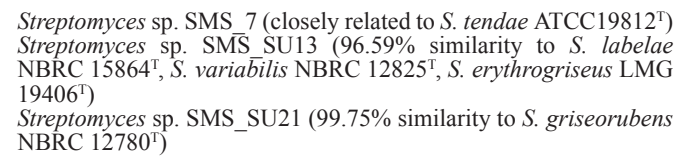 & {$[153]$} \\
\hline \multirow{3}{*}{$\begin{array}{l}\text { Water } \\
\text { sample }\end{array}$} & \multirow[t]{3}{*}{ India } & Aquaculture water from & 4 & ns & {$[154]$} \\
\hline & & Vellore, Tamilnadu & & & \\
\hline & & Seawater from Visakhapatnam & 1 & S. rochei MTCC 10109 & {$[155]$} \\
\hline \multirow[t]{4}{*}{$\begin{array}{l}\text { Marine } \\
\text { sponges }\end{array}$} & \multirow[t]{2}{*}{ India } & $\begin{array}{l}\text { marine sponges (Callyspongia diffusa, My- } \\
\text { cale mytilorum, Tedania anhelans, Dysidea } \\
\text { fragilis) } \\
\text { from Vizhinjam port, (Lat. 8'22'30’N, Long. } \\
76^{\circ} 59^{\prime}, 16^{\prime \prime} \text { ) south west coast India. }\end{array}$ & 10 & $\begin{array}{l}\text { Streptomyces } \mathrm{sp} . \mathrm{AQBCD} 03 \\
\text { Streptomyces } \mathrm{sp} . \mathrm{AQBCD} 11 \\
\text { Streptomyces } \mathrm{sp} \text {. AQBCD24 } \\
\text { Streptomyces } \mathrm{sp} \text {. AQBMM35 } \\
\text { Streptomyces } \mathrm{sp} \text {. AQBMM49 } \\
\text { Streptomyces } \mathrm{sp} \text {. AQBTA66 } \\
\text { Streptomyces sp. AQBDF81 }\end{array}$ & {$[156-158]$} \\
\hline & & $\begin{array}{l}\text { Kovalam coast, West coast of Kerala } \\
\left(8^{\circ} 23^{\prime} \mathrm{N}, 76^{\circ} 57^{\prime} \mathrm{E}\right) .\end{array}$ & ns & ns & [47] \\
\hline & China & $\begin{array}{l}\text { Mycale sp. from } \\
\text { sea area of Gulei Port, Fujian, China (Lat. } \\
\text { 23.74, Long. 117.59) }\end{array}$ & 3 & $\begin{array}{l}\text { HNS054 ( } 99 \% \text { S. labedae) } \\
\text { HNS049 (S. microflavus) } \\
\text { HNS056 (S. flaveus) }\end{array}$ & {$[159]$} \\
\hline & Egypt & Red Sea & 1 & $\begin{array}{l}\text { Streptomyces sp. HC9 (accession number JQ929061) 97\% Strepto- } \\
\text { myces rochei SBPL-21 }\end{array}$ & {$[160]$} \\
\hline \multirow[t]{3}{*}{$\begin{array}{l}\text { Marine } \\
\text { corals }\end{array}$} & India & $\begin{array}{l}\text { Mucus of coral, } A \text {. digitifera from Hare } \\
\text { Island }\left(9^{\circ} 12^{\prime} \mathrm{N}, 79^{\circ} 5^{\prime} \mathrm{E}\right) \text {, Gulf of Mannar, } \\
\text { Tamilnadu }\end{array}$ & 6 & $\begin{array}{l}\text { Streptomyces } \mathrm{sp} . \text { CA3 }(99.8 \% \text { S. akiyoshiensis FJ486367.1) } \\
\text { Streptomyces } \mathrm{sp} \text {. CA4 }(96.7 \% \text { Streptomyces } \mathrm{sp} \text {. EU523135.1) } \\
\text { Streptomyces } \mathrm{sp} \text {. CA5 } \\
\text { Streptomyces } \mathrm{sp} \text {. CA9 } \\
\text { Streptomyces } \mathrm{sp} \text {. CA15 } \\
\text { Streptomyces } \mathrm{sp} \text {. CA18 }(96.7 \% \text { Streptomyces sp. EU523135.1) }\end{array}$ & {$[161]$} \\
\hline & \multirow[t]{2}{*}{ China } & $\begin{array}{l}\text { Gorgonian coral (E. aurantiaca, } M . \text { squa- } \\
\text { mata, } M \text {. flexuosa, S. suberosa, V. umbracu- } \\
\text { lum) from Sanya coral reef conservation } \\
\left(18^{\circ} 11^{\prime} \mathrm{N}, 109^{\circ} 25^{\prime} \mathrm{E}\right) \text {, South China sea }\end{array}$ & 3 & $\begin{array}{l}\text { Streptomyces sp. ZXY018 } \\
\text { Streptomyces sp. ZXY077 } \\
\text { Streptomyces sp. ZXY090 }\end{array}$ & {$[162]$} \\
\hline & & Lu Hui Tou fringing reef & 3 & $\begin{array}{l}\text { SCSIO } 11527 \text { (S. fimicarius ISP5322 100\%) } \\
\text { SCSIO } 11469 \text { (S. rutgersensis NBRC } 12819100 \%) \\
\text { SCSIO } 11531 \text { (S. variabilis NBRC } 1282599.859 \%) \\
\text { SCSIO } 11717 \text { (S. viridodiastaticus NBRC } 13106100 \%)\end{array}$ & {$[163]$} \\
\hline \multirow[t]{3}{*}{ Fishes } & \multirow[t]{3}{*}{ India } & $\begin{array}{l}\text { Ornamental fish, Chaetodon callare (red tail } \\
\text { butterfly), Archamia fucata (orange-lined } \\
\text { cardinal) from } \\
\text { Vizhinkam port, India } \\
\text { Vizhinjam port, ( } 8^{\circ} 22^{\prime} 30^{\prime \prime} \mathrm{N}, 7^{\circ} 59^{\prime} 16^{\prime} \mathrm{E} \text { ) } \\
\text { southwest coast of India }\end{array}$ & 7 & $\begin{array}{l}\text { AQBCC06 } \\
\text { AQBCC } 20 \\
\text { AQBCC } 24 \\
\text { AQBCC } 40 \\
\text { AQBCC } 51 \\
\text { AQBCC } 54 \\
\text { AQBCC } 75\end{array}$ & [164] \\
\hline & & $\begin{array}{l}\text { Marine - Epinephelus diacanthus (grouper), } \\
\text { estuarine - Oreochromis mossambicus } \\
\text { (tilapia), fresh-water - Cyprinus carpio } \\
\text { (common carp) from Vizhinjam, Veli, Centre } \\
\text { for Aquatic and Research Extension }\end{array}$ & ns & Streptomyces sp. & {$[165]$} \\
\hline & & Red snapper from & ns & ns & {$[166]$} \\
\hline
\end{tabular}




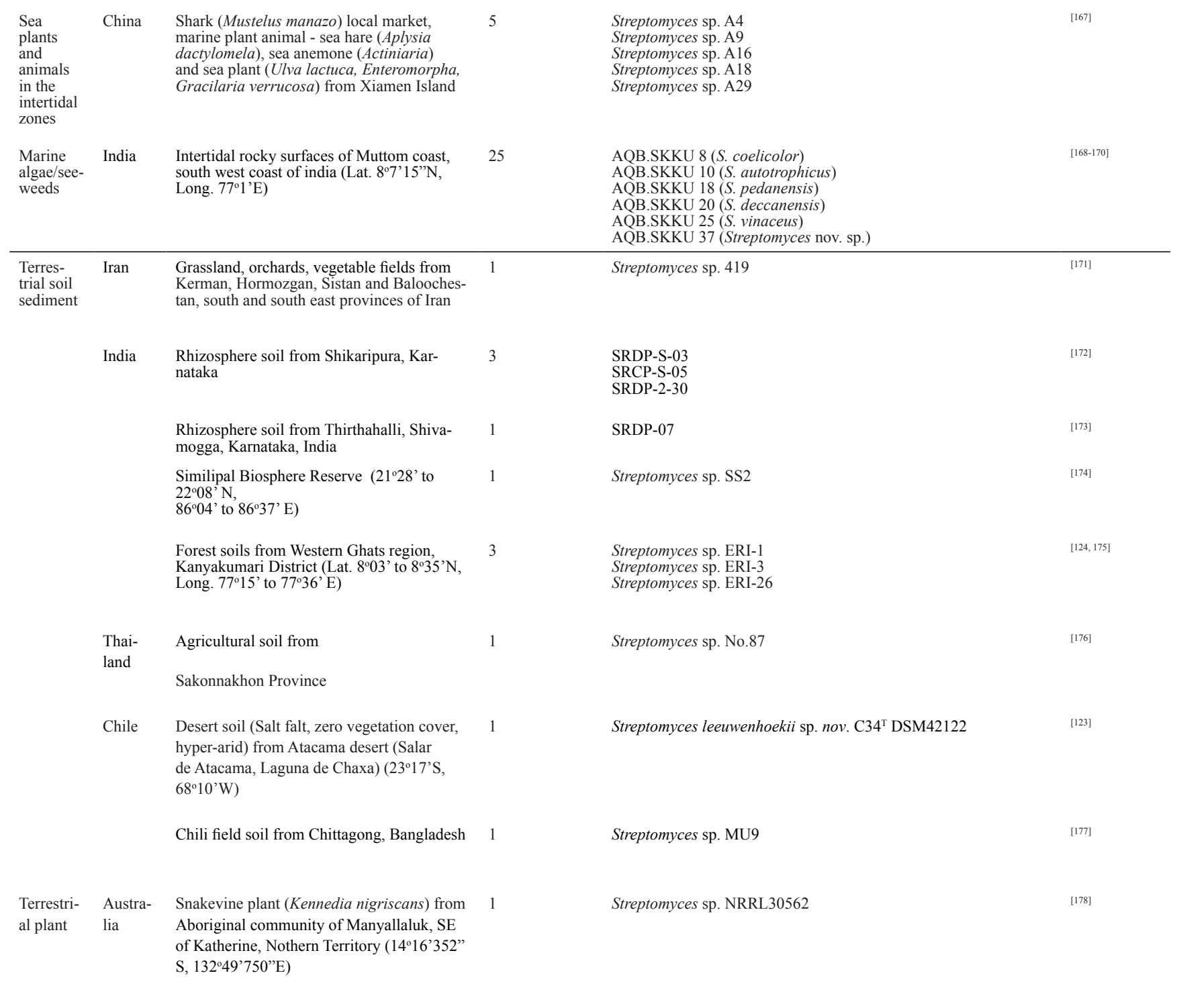

*ns - not specified

There were significant lower number of studies reported Streptomyces with anti-Vibrio activity from the terrestrial environments as compared to the much higher number of studies on the marine Streptomyces. The higher isolation rate of Streptomyces strains from marine environment could be due to the recent interest of researchers toward the marine natural products discovery as many novel bacteria genus and species with production of novel compounds have been identified from the marine environment ${ }^{[179-181]}$. In another context, these phenomena seem to imply that the resources which can be accessed easily had been exhausted as extensive studies on the terrestrial soil derived microorganisms were observed over the years. The recurrent isolation and screening of the predominant species from the environments have resulted in rediscovery of known compounds which is a major problem faced in drug discovery. As reported, similar well-known and structurally-related antibacterial compounds were discovered from the Streptomyces isolated from different terrestrial environments ${ }^{[182]}$.

To support the hypothesis that marine Streptomyces is a better source for anti-Vibrio activity, comparison between the efficacy of the metabolites produced by the anti-Vibrio Streptomyces isolated from respective environments were performed. To render easier inter-study comparison, the anti-Vibrio activity of the Streptomyces from each study was represented by the highest inhibition zone reported. The efficacy of the anti-Vibrio metabolites produced by Streptomyces isolated from respective source was obtained based on the median inhibition zone of respective site of isolation. These antiVibrio Streptomyces strains were then categorized into four different groups based on their source of isolations. According to Table 2, it shows that the strength of antiVibrio activity displayed by each group and the ranking is as follow, mangrove sediment $(21.0 \mathrm{~mm})>$ marine organisms (plants and animals) $(18.0 \mathrm{~mm})$, terrestrial soil $(18.0 \mathrm{~mm})>$ marine sediment $(15.01 \mathrm{~mm})$. The antiVibrio Streptomyces isolated from the respective isolation source with differential strength against Vibrio sp. were discussed as follow. 
Table 2. Comparing the anti-Vibrio efficacy of Streptomyces from different environment sources.

\begin{tabular}{lc}
\hline $\begin{array}{l}\text { Source of isolation } \\
\text { Terrestrial soil }\end{array}$ & $\begin{array}{c}\text { Median of inhibition zone } \\
(\mathrm{mm})\end{array}$ \\
Marine sediment and water & $18.00(\mathrm{n}=7)$ \\
Mangrove soil & $21.00(\mathrm{n}=10)$ \\
Marine organisms & $18.00(\mathrm{n}=8)$ \\
\hline
\end{tabular}

\section{Terrestrial environments}

The number of undiscovered antimicrobials from Streptomyces and the estimated number of antibiotics still be discovered from Actinobacteria could be well above $10^{5}$ as predicted with the use of mathematical models ${ }^{[183]}$. Furthermore, new species of Streptomyces are being identified every day, indicating that our knowledge on this genus is still far from exhaustive. Hence, continuous effort has to be put into the exploitation of Streptomyces from terrestrial regions by taking advantage of underexplored ecological niches as demonstrated by several groups of researchers that discovered Streptomyces with anti-Vibrio activity. This study identified a total of 11 strains of Streptomyces with anti-Vibrio activity were found from different types of terrestrial soils and an endophytic Streptomyces isolated from a terrestrial plant ${ }^{[178]}$. The Streptomyces with anti-Vibrio activity were isolated from a wide variety of the terrestrial soils ranging from the commonly accessible agriculture soils ${ }^{[176]}$, forest soils ${ }^{[124]}$, grassland and orchard soils ${ }^{[171,}$ ${ }^{177]}$ to the more extreme environments such as the hyper arid desert soil ${ }^{[123]}$ and arctic sediments ${ }^{[184]}$.

The detailed locations for the sources of isolation of the Streptomyces with anti-Vibrio activity were described in Table 1. Rateb et al. (2011) ${ }^{[123]}$ reported a desert soil derived Streptomyces strain C34 produced rare 22-membered macrolactone polyketides, known as chaxalactins A-C (1-3) with anti-Vibrio activity. A recent report determined that this Streptomyces strain C34 represents a new species and named as Streptomyces leeuwenhoekii sp. nov., a strain showing high potential for drug discovery with total genome size of around $7.86 \mathrm{Mb}{ }^{[185]}$. The site of isolation of this novel species of Streptomyces is from the hyper-arid and high-attitude Atacama Desert located in Chile $\left(23^{\circ} 17^{\prime} \mathrm{S}, 68^{\circ} 10^{\prime} \mathrm{W}\right)$. The three macrolactone polyketides including the chaxalactins A (1), B (2) and C (3) displayed a minimum inhibitory concentration of $12.5,20$ and $12.5 \mu \mathrm{g} / \mathrm{mL}$ against the pathogen $V$. parahaemolyticus NCTC10441 ${ }^{[123]}$ which was isolated from the feces sample of a patient with gastroenteritis. The molecular structures of the chaxalactins were depicted in Figure 2. Meanwhile, an endophytic Streptomyces NRRL30562 isolated from snakevine plant (Kennedia nigriscans) was found to produce newly described antibiotics, named as munumbicin B (4), C and D [structures of munumbicin $\mathrm{C}$ and $\mathrm{D}$ have not been elucidated]; that displayed antibacterial activity against $V$. fischeri PIC345 with inhibition zones measured at $16 \mathrm{~mm}, 9 \mathrm{~mm}$ and $12 \mathrm{~mm}$ respectively at $10 \mu \mathrm{g}$ concentration ${ }^{[178]}$.

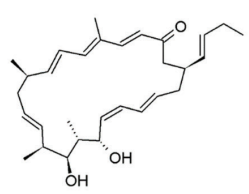

(1)

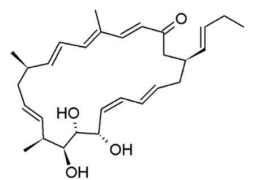

(2)

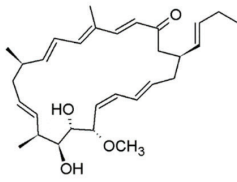

(3)

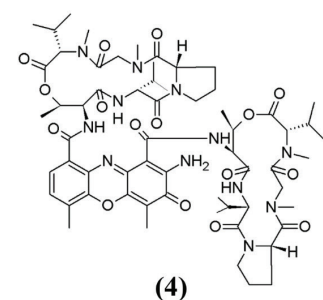

(4)

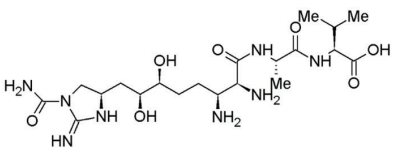

(5)

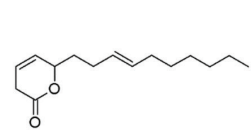

(6)

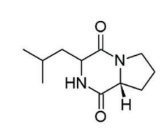

(7)

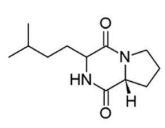

(8)

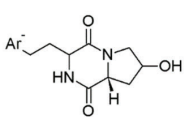

(9)

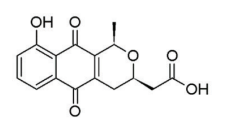

(10)

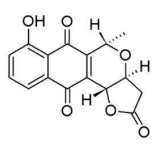

(11) 
Besides the direct antagonism of Streptomyces against Vibrio sp. by direct killing of the microorganism or impeding microbial growth, the bioactive products derived from Streptomyces sp. also exhibited activity that interferes with the expression of pathogenic traits of Vibrio pathogens ${ }^{[186,}$ ${ }^{187]}$. Augustine et al. (2012) ${ }^{[184]}$ reported the $20 \%$ culture supernatant of strains Streptomyces A733 and A745 isolated from arctic sediment (Ny-Alesund, an island in Svalbard Archipelago $\left(79^{\circ} 55^{\prime} \mathrm{N}, 1^{\circ} 56^{\prime} \mathrm{E}\right)$ reduced the biofilm formation of $V$. cholerae $\mathrm{O} 1 \mathrm{MCV} 09$ by $88 \%$ and $80 \%$ respectively. Furthermore, an antivirulence compound, known as guadinomine B (5) was produced by a strain Streptomyces sp. K01-0509 isolated from soil sample collected from the Amami Oshima, Kagoshima, Japan ${ }^{[186]}$. The guadinomine B (5) was reported to be potent in inhibiting the type III secretion system (TTSS) of gram-negative bacteria, including most of the pathogenic Vibrio sp. that utilize this apparatus for protein secretion and translocation as their primary virulence mechanism with $\mathrm{IC}_{50}$ at $14 \mathrm{nM}^{[188]}$. Another study showed that the soil-derived $S$. mobaraensis DSM40847 ${ }^{\mathrm{T}}$ from Mobara city, Japan, produced endoprotease inhibitors that against cysteine protease papain which is known to be virulence factors involved in bacterial pathogenicity [187]. The endoprotease inhibitor was known as Streptomyces papain inhibitor (SPI) which exhibits inhibitory effect on the growth of wide range of Gram-positive and Gramnegative bacterial pathogens. The addition of $10 \mu \mathrm{M}$ of SPI was shown to be bactericidal toward $V$. cholerea serotype O1 (ATCC 14035). This study suggested that SPI could be a potential novel broad-spectrum antimicrobial agent for clinically relevant infectious diseases ${ }^{[187]}$.

\section{Aquatic environments}

Marine environments are the largest source of microbes and new secondary microbial metabolites. The marine sources ranging from the seashore soil sediments to the depths of 10,000 metres ${ }^{[189]}$ are rich sources of microbes. Furthermore, marine environment contains wide range of distinct microorganisms that are not present in terrestrial environment ${ }^{[45,190,191]}$. This may be attributed to the extremely different physical and chemical conditions as compared to the terrestrial conditions. It has been suggested that marine Actinobacteria exhibit distinct characteristics from those terrestrial counterparts and therefore produce more potentially novel bioactive compounds ${ }^{[190,192]}$. Thus, marine environment is a potential source for isolation of novel Actinobacteria in which increasing evidences on the discovery of novel antibiotic and industrially important enzyme from marine Actinobacteria ${ }^{[193-196]}$. Likewise, $80 \%$ of the reviewed studies demonstrated the isolation of Streptomyces with anti-Vibrio activity from aquatic environments such as marine sediments, marine invertebrates and mangrove ecosystems.

\section{Marine sediments}

Based on the literatures collected, a total of 38 strains of Streptomyces with anti-Vibrio activity were isolated from marine sediments of diverse geographical locations. These diverse geographical locations include coastal lagoon sediment ${ }^{[144]}$, near-shore sediment ${ }^{[131]}$, shrimp culture pond ${ }^{[146]}$ and submarine sediment (45m underwater) ${ }^{[139]}$. Streptomyces species found in virgin soil is expected to pro- duce broad-spectrum antimicrobial compounds, hence rendering them to be successful in outcompeting others and effectively colonize the newly formed soil. Mitra et al. (2011 $)^{[197]}$ suggested that the specific area favorable for obtaining maximum number of isolates with broadspectrum activity in an estuarine setting is limited to the narrow band between the mean high and low tide marks. In brief, the samples collected from sites influenced by tides were suggested to exhibit a high antagonistic potential ${ }^{[198]}$. Mitra et al. $(2008)^{[198]}$ believed that antibacterial compound is required to aid in colonizing a newly formed top soil during the transition periods between high and low tides, thereby the periodic oscillations of dry and wet conditions trigger more antagonistic activity of Actinobacteria. In agreement with observations of Mitra et al. (2011) ${ }^{[197]}$, several marine sediment derived Streptomyces strains exhibiting broad antibacterial spectrum and surfactants producing ability were isolated from area constantly affected by tidal gradient in Minnie Bay, A \& N islands, India ${ }^{[199]}$. Furthermore, the high nutrient availability and osmotic flux in the sampling site could be another reason for the broad-spectrum activities exhibited by these strains. For example, the ethyl acetate extract of the Streptomyces sp. NIOT-VKKMA02 displayed the maximum inhibitory activity against a classical O1, hypertoxigenic strain $V$. cholerae 569B (MTCC3904) with $20 \mathrm{~mm}$ inhibition zone measured at concentration of 50 $\mu \mathrm{g}{ }^{[199]}$. Furthermore, studies demonstrated the purified DOPA melanin produced by Streptomyces sp. MVSC13 and MVCS6 isolated from the marine sediment of Versova coast, Mumbai, India (Lat. 19²8'26.32'N, Long. $72^{\circ} 48^{\prime} 07.21^{\prime \prime E}$ ) exhibiting strong antibacterial activity against several fish and human Vibrio pathogens [137, 138]. Specialized media (Tyrosine asparagine medium) was employed to cultivate Streptomyces sp. MVSC13 and MVSC6 for the production of DOPA melanin which displayed good activity against Vibrio sp. FPO5 (from infected region of Carassius auratus, $16 \mathrm{~S}$ rRNA 98\% $\mathrm{V}$. parahaemolyticus) $(15 \pm 0.01 \mathrm{~mm}), V$. fluvialis RMMH10 (12 $\pm 0.02 \mathrm{~mm}), V$. splendidus RMMH11 $(9 \pm 0.02 \mathrm{~mm}), V$. parahaemolyticus RMMH12 (15 \pm 0.03$)^{[137,138]}$. Moreover, a new pyranosesquiterpene compound (6) was discovered from a strain Streptomyces sp. SCSIO 01689 isolated from submarine sediment, located $45 \mathrm{~m}$ underwater of northern South China Sea (18 $\left.11^{\prime} \mathrm{N}, 109^{\circ} 32^{\prime} \mathrm{E}\right)$. The isolation of Streptomyces sp. SCSIO 01689 and the preparation method for its production of cyclic peptide type compounds were patented ${ }^{[139]}$. The patent disclosed the cyclic peptide type compounds, pyranosesquiterpene compound (6), Cyclo(D)-Pro-(D)-Ile (7), Cyclo(D)-Pro-(D)-Leu (8) and Cyclo(D)-trans-4-OH-Pro-(D)-Phe (9) exhibited potent anti-Vibrio activity, specifically against $V$. anguillarum with MIC measured at >100, 0.05, 0.04 and 0.07 $\mu \mathrm{g} / \mathrm{mL}$. Besides that, You et al. (2007) ${ }^{[200]}$ indicated the metabolite of Streptomyces sp. A66 isolated from marine sediment was found to be effective in reducing the development of antibiofilm in Vibrio sp. The strain attenuated the biofilm formation of $V$. harveyi with $99.3 \%$ of inhibition rate and $74.6 \%$ of degradation rate at concentration of $2.5 \%(\mathrm{v} / \mathrm{v})^{[140]}$. Another study also indicated that the antibiofilm activity of Streptomyces sp. A66 involved in the inhibition of the quorum sensing system of Vibrio sp. by reducing the $\mathrm{N}$-acylated homoserine lactones activity 
${ }^{[200]}$. The $N$-acylated homoserine lactones are responsible for the coordination of virulence expression in response to density of surrounding bacterial population ${ }^{[200]}$.

\section{Mangrove environment}

Mangroves are located along the intertidal zones of estuaries, backwaters, deltas, marshes and mudflats along the tropical and subtropical regions. Mangrove ecosystem is a unique ecological niche which contains highly productive and diverse microbial community ${ }^{[201-204]}$. Similarly, the mangrove environment has been known to be potent reservoir for isolation of antibiotic-producing Actinobacteria ${ }^{[205]}$. Eccleston et al. (2008) ${ }^{[206]}$ revealed that the ecology has great impact on the diversity of Actinobacteria. Higher population of Actinobacteria was isolated from mangrove mud sediments than the benthic communities associated with littoral sand sediments, freshwater creek and lake habitats. Eccleston et al. (2008) ${ }^{[206]}$ suggested the low numbers of Actinobacteria from freshwater habitats and littoral sand sediments could be attributed to the low organic nutrient levels as compared to high nutrient habitats such as mangrove mud ${ }^{[206]}$. Accordingly, Hong et al. (2009) ${ }^{[35]}$ also demonstrated the abundance of bioactive strains is correlated with ecological influences. A low number of bioactive strains was recorded from soil containing more sand and less organic matter while rhizosphere soil was rich source of bioactive strains ${ }^{[35]}$.

By comparing the different isolation sources, the data showed that the Streptomyces strains derived from mangrove soil displayed the strongest antibacterial activity against Vibrio sp. with the highest median inhibition zone $(21.0 \mathrm{~mm})$, followed by marine sediment $(15.0 \mathrm{~mm})$, marine organisms $(18.0 \mathrm{~mm})$ and terrestrial soil $(18.0 \mathrm{~mm})$. This observation suggests that mangrove environments provides a better site for isolation of Streptomyces strains with $39.9 \%$ higher anti-Vibrio activity than those from marine sediment and water.

Mohana and Radhakrishnan (2014) ${ }^{[149]}$ reported an antiVibrio Streptomyces sp. strain MA7 from mangrove rhizosphere sediment collected from Vellar estuary region at Parangipettai, Tamilnadu, India $\left(11.4900^{\circ} \mathrm{N} ; 79.7600^{\circ} \mathrm{E}\right)$. Strain MA7 displayed antibacterial activity towards several Vibrio sp. pathogens including $V$. mimicus, $V$. cholerae $\mathrm{O} 1, V$. cholerae $\mathrm{O} 139$ and $V$. parahaemolyticus. The methanol extract of strain Streptomyces sp. MA7 exhibited strong antibacterial activity against $V$. parahaemolyticus with 21 $\mathrm{mm}$ inhibition zone measured at concentration of $250 \mu \mathrm{g}$ ${ }^{[149]}$. Furthermore, an aliphatic compound named as $N$-isopentyltridecanamide was identified from the ethyl acetate extract of strain Streptomyces ECR77 (16S rRNA 99\% S. labedae) isolated from the mangrove sediment of East coast region, Pichavaram mangrove forest (Lat. $11.43^{\circ} \mathrm{N}$, Long. $79.77^{\circ} \mathrm{E}$ ). The ethyl acetate extract of Streptomyces ECR77 showed the maximum inhibitory activity against $V$. cholerae, V. parahaemolyticus and $V$. alginolyticus with inhibition zones $13.66 \pm 0.47 \mathrm{~mm}, 9.66 \pm 0.94$ and $16.33 \pm 0.47 \mathrm{~mm}$ measured at $25 \mu \mathrm{L}$ concentration ${ }^{[152]}$. Similarly, Sengupta et al. (2015) $)^{[153]}$ isolated three mangrove derived anti-Vibrio Streptomyces in Sundarbans, they displayed high antibacterial activity against $V$. cholerae (MCTC 3906) with the inhibition zone measured more than $25 \mathrm{~mm}$ and minimum inhibitory concentration at $50 \mu \mathrm{g} / \mathrm{mL}$.

\section{Marine animals and plants}

Streptomyces species is also found to form symbioses with other organisms, most notably plants and invertebrates. In many cases, Streptomyces species showed protective mutualistic symbioses with the host in which the host provides nutrients and protections for the bacteria while the bacteria produce antibiotics to protect host from pathogens $[49$, ${ }^{207]}$. Researches have indicated marine invertebrates which are sessile, such as sponges and corals are great sources of marine bioactive metabolites. These bioactive metabolites in these marine organisms were produced by the marine bioactive metabolite producing microorganisms as symbiotic relationships. For instance, theopaulauamide, an antifungal bicyclic glycopeptide isolated from Palauan sponge, Theonella swinhoei has been confirmed to be originated from a novel delta-proteobacterium known as Candidatus Entotheonella palauensis, served as one of the first experimental evidences for microbial derived compounds from sponge ${ }^{[208]}$.

There has been an increasing evidence of sponges and corals as the potential sources for isolation of Streptomyces with anti-Vibrio activity. The comparison made earlier revealed that the Streptomyces isolated from marine organisms, such as sponges and corals, represent alternative sources for anti-Vibrio Streptomyces. These Streptomyces were isolated from marine sponges such as the Callyspongia diffusa, Mycale mytilorum, Tedania anhelans and Dysidea fragilis collected from Vizhinjam port (Lat. 8'22'30", Long. 76 59'16”E) located at Southwest coast of India ${ }^{[157]}$. The ethyl acetate extracts of these Streptomyces strains exhibited diverse strength of antibacterial activity toward both human and fish Vibrio pathogens such as the $V$. harveyi, $V$. parahaemolyticus and $V$. alginolyticus with maximum inhibition zone measured up to $30 \mathrm{~mm}$ at $50 \mu \mathrm{g}$ concentration $^{[156]}$. Su et al. $(2014)^{[159]}$ reported the isolation of Streptomyces sp. HNS054 (16S rRNA 99\% similarity to $S$. labedae) from marine sponges, Mycale sp. collected from Gulei Port, Fujian, China (Lat. 23.74, Long. 117.59) exhibiting antibacterial activity against both V. parahaemolyticus and $V$. diabolicus, with 10-15 mm inhibition zone observed against $V$. parahaemolyticus. The study suggested that Streptomyces sp. strain HNS054 may play an important in conferring a chemical defensive mechanism to protect the sponges from pathogenic Vibrio sp. which are associated with mortality of marine animals ${ }^{[159]}$. The detection of these Streptomyces strains with secondary metabolite production further support the facts that sponges or marine invertebrates are important source of biologically active compounds ${ }^{[209,210]}$.

Coral is also a potential source to isolate Streptomyces sp. with genetic capacity to produce diverse potentially bioactive molecules which may contribute to the chemical defense of coral holobionts ${ }^{[162,163]}$. There were 4 studies $(6 \%)$ reported the isolation of Streptomyces with anti-Vibrio activity from different species of corals, including the Acropora digitifera ${ }^{[211]}$, Melitodes squamata ${ }^{[212]}$, Porites lutea, Galaxea fascicularis ${ }^{[213]}$, Sarcophyton glaucum ${ }^{[160]}$. Li et al. (2014) ${ }^{[213]}$ reported a total of four different species of Streptomyces with anti-Vibrio activity in the coral 
samples collected from Lu Hui Tou fringing reef $\left(18^{\circ} 13^{\prime} \mathrm{N}\right.$, $\left.109^{\circ} 28^{\prime} \mathrm{E}\right)$. The ethyl acetate extracts of these Streptomyces showed different degree of anti-Vibrio activity against both pathogenic $V$. coralliilyticus ATCC BAA-450 isolated from diseased coral Pocillopora damicornis and V. alginolyticus serotype XII ATCC 17749 isolated from spoiled horse mackerel which caused food poisoning. The highest anti-Vibrio activity was displayed by Streptomyces sp. SCSIO11717 (16S rRNA 100\% S. viridodiastatitus NBRC13106) with zone of inhibition of $12.3 \pm 2.5 \mathrm{~mm}$ measured at $20 \mathrm{mg} / \mathrm{mL}$ as compared to the standard drug, ciprofloxacin $(20 \mathrm{mg} / \mathrm{mL})$ with $15 \pm 1 \mathrm{~mm}$ against the pathogenic V. alginolyticus ${ }^{[213]}$. Furthermore, Streptomyces sp. SCSIO 11527 (16S rRNA 100\% S. fimicarius) with anti-Vibrio activity isolated from coral Galaxea fascicularis was positive for PKS-II gene with $90 \%$ similarity to ketoacyl synthase from $S$. argillaceus, suggesting its potential in producing anthracycline-related compounds ${ }^{[163]}$. This finding was supported with one of the previous study demonstrated the production of nanaomycins A (10) and D (11) by Streptomyces rosa var. notoensis OS-3966 isolated from a soil sample collected at Nanao-shi in Noto Peninsula, Japan [214]. The study showed that both nanaomycins A (10) and D (11), anthracycline/anthraquinone antibiotics exhibited strong inhibitory activity against both marine pathogens, $V$. alginolyticus 138-2 and V. parahaemolyticus K-1 [214].

Besides marine sponges and corals, seaweed is also another source for anti-Vibrio Streptomyces. There were 3 studies reported the presence of Streptomyces with antiVibrio activity from seaweeds collected from intertidal rocky surfaces at Muttom coast, Southwest coast of India $\left(8^{\circ} 7^{\prime} 15^{\prime \prime} \mathrm{N}, 77^{\circ} 1\right.$ 'E) ${ }^{[170]}$. According to Hollants et al. (2013) ${ }^{[215]}$, the macroalgal-bacterial interactions are not unusual. In fact, it has been evidenced that the production of antimicrobial compounds by the microorganism is to protect the algae surface from pathogens, herbivores and fouling organisms. Interestingly, a strain Streptomyces sp. strain AQB.SKKU20 derived from seaweed was expressing antagonistic activity towards Vibrio sp. after the exposure to ethidium bromide, suggested that the mutations induced by ethidium bromide stimulates antibiotic production ${ }^{[168]}$. Furthermore, study also indicated that Streptomyces with anti-Vibrio activity isolated from seaweeds could be used as probiotics and biocontrol agents against vibriosis in aquaculture ${ }^{[169]}$. This study demonstrated that the incorporation of the anti-Vibrio strains of Streptomyces in the probiotic feed resulted in higher percentage of survival rate of Macrobrachium rosenbergii prawn juveniles with no external disease manifestations after challenged with pathogenic $V$. vulnificus at $10^{5} \mathrm{CFU} / \mathrm{mL}$ which caused up to $79.2 \%$ mortality in control group with no Streptomyces as probiotic ${ }^{[169]}$.

\section{APPLICATION OF ANTI-VIBRIO COM- POUNDS PRODUCING STREPTOMYCES sp. IN AQUACULTURE}

Streptomyces sp. constitute a group of industrially and clinically important microorganisms ${ }^{[40,42,115,216]}$ that produce valuable compounds including antibiotics ${ }^{[41]}$, antitumor agents, antiparasitic, immunosuppressive agents and enzymes ${ }^{[45]}$. Being the fact having an immense potential for bioactive secondary metabolites production, Streptomyces has the advantage of producing potential antagonistic and antimicrobial compounds can be valuable as biocontrol agent against Vibrio pathogens in aquaculture [217]. The production of antagonistic compounds renders Streptomyces sp. capable to compete for nutrients and attachment sites in the host. For example, Streptomyces sp. was reported to produce siderophores which could influence the growth of pathogenic Vibrio sp. ${ }^{[140]}$. Siderophores are ferric ion-specific chelating agents which aiding the Streptomyces sp. to compete for iron in the aquatic environment ${ }^{[218]}$. Studies have indicated that the intracellular iron concentration is essential for biofilm formation and development in bacteria and also the Vibrio sp. ${ }^{[219-221]}$. Mey et al. $(2005)^{[221]}$ revealed the wild-type $V$. cholerae suffered poor biofilm formation in iron-deficient medium and also elucidated the role $r h y B$ gene in iron homeostasis to biofilm formation as the $r h y B$ mutant $V$. cholerae was unable to form wild-type biofilm in low-iron medium. Biofilm formation plays many imperative roles in Vibrio $\mathrm{sp}$. for their survival, virulence and environmental stressors resistance ${ }^{[53]}$. Biofilms serve to render Vibrio sp. more protected and less susceptible to antimicrobial agents and hence difficult to control. The discovery of Streptomyces strains with ability to produce siderophores is providing a new approach in controlling Vibrio sp. in aquaculture settings as biofilms are considered a reservoir for some pathogenic Vibrio sp. that can cause detrimental effects on the cultured livestock in aquaculture. Moreover, studies also revealed the production inhibitory compounds with anti-quorum sensing ${ }^{[200]}$ and anti-virulence activities ${ }^{[186]}$ targeting Vibrio sp. by Streptomyces sp. These promising anti-Vibrio activities also further strengthen the view of the applicability of Streptomyces in aquaculture as an alternative biocontrol agent against Vibrio sp. ${ }^{[217]}$.

\section{CONCLUSION}

There is an urgent need to search for new therapeutic drugs, especially antibiotics due to the rapid increase of resistance in Vibrio sp. pathogens to the major frontline antibiotics. Thus, extensive effort is required by the researchers focusing on the screening and isolation of promising strains of Streptomyces with antimicrobial properties. The information and knowledge obtained in this review could help in selecting the potential sources of isolation and as a guide for future bioprospectors in finding antibiotic-producing Streptomyces, especially against Vibrio spp. Based on the findings of this review, mangrove sediment could be a better source for Streptomyces with anti-Vibrio activity. Nevertheless, there is still limited studies on the investigation of the exact antibacterial mechanisms of these Streptomyces derived bioactive metabolites against the Vibrio pathogens. Therefore, future studies on the elucidating the antibacterial mechanisms of these Streptomyces are warranted. As a whole, these anti-Vibrio Streptomyces represent a valuable source for future development of clinically important drugs to treat infections caused by V. cholerae, V. parahaemolyticus and $V$. vulnificus in clinical settings as well as to be applied as probiotics to control vibriosis in aquaculture. 


\section{Author Contributions}

The literature review and manuscript writing were performed by LT-HT, L-HL and B-HG. L-HL and B-HG founded the research project.

\section{Conflict of Interest}

The authors declare that the research was conducted in the absence of any commercial or financial relationships that could be construed as a potential conflict of interest.

\section{Acknowledgments}

This work was supported by the Monash University Malaysia ECR Grant (5140077-000-00), MOSTI eScience Fund (02-02-10-SF0215 and 06-02-10-SF0300).

\section{Reference}

1. Hixson SM, Fish nutrition and current issues in aquaculture: the balance in providing safe and nutritious seafood, in an environmentally sustainable manner. J Aquac Res Dev 2014; 5(234): 2.

2. Law JW-F, Ab Mutalib N-S, Chan K-G, et al., Rapid methods for the detection of foodborne bacterial pathogens: principles, applications, advantages and limitations. Front Microbiol 2015; 5: 770.

3. Law JW-F, Ab Mutalib N-S, Chan K-G, et al., An insight into the isolation, enumeration, and molecular detection of Listeria monocytogenes in food. Front Microbiol 2015; 6: 1227.

4. Cheah Y-K, Salleh NA, Lee L-H, et al., Comparison of PCR fingerprinting techniques for the discrimination of Salmonella enterica subsp. enterica serovar Weltevreden isolated from indigenous vegetables in Malaysia. World J Microbiol Biotechnol 2008; 24(3): 327.

5. Khoo C-H, Cheah Y-K, Lee L-H, et al., Virulotyping of Salmonella enterica subsp. enterica isolated from indigenous vegetables and poultry meat in Malaysia using multiplex-PCR. Antonie Van Leeuwenhoek 2009; 96(4): 441.

6. Lee LH, Cheah YK, Shiran M, et al., Molecular characterization and antimicrobial resistance profiling of Salmonella enterica subsp. enterica isolated from 'Selom'(Oenanthe stolonifera). Int Food Res J 2009; 16(1): 191-202.

7. Eng S-K, Pusparajah P, Ab Mutalib N-S, et al., Salmonella: a review on pathogenesis, epidemiology and antibiotic resistance. Front Life Sci 2015; 8(3): 284-293.

8. Letchumanan V, Yin WF, Lee LH, et al., Prevalence and antimicrobia susceptibility of Vibrio parahaemolyticus isolated from retail shrimps in Malaysia. Front Microbiol 2015; 6: 33.

9. Heng S-P, Letchumanan V, Deng C-Y, et al., Vibrio vulnificus: an environmental and clinical burden. Front Microbiol 2017; 8: 997.

10. Law JWF, Letchumanan V, Chan KG, et al., Insights into detection and identification of foodborne pathogens. Edited by Om V. Singh. Food Borne Pathogens and Antibiotic Resistance. WILEY Blackwell 2016.

11. Letchumanan V, Wong P-C, Goh B-H, et al., A review on the characteristics, taxanomy and prevalence of Listeria monocytogenes. Prog Microb Mol Biol 2018; 1(1)

12. Garrido-Maestu A, Lozano-León A, Rodríguez-Souto RR, et al., Presence of pathogenic Vibrio species in fresh mussels harvested in the southern Rias of Galicia (NW Spain). Food Control 2016; 59: 759-765.

13. Hou CC, Lai CC, Liu WL, et al., Clinical manifestation and prognostic factors of non-cholerae Vibrio infections. Eur J Clin Microbiol Infect Dis 2011; 30(6): 819-24

14. Horseman MA and Surani S, A comprehensive review of Vibrio vulnificus: an important cause of severe sepsis and skin and soft-tissue infection. Int J Infect Dis 2011; 15(3): e157-66.

15. Letchumanan V, Chan KG, and Lee LH, Vibrio parahaemolyticus: a review on the pathogenesis, prevalence, and advance molecular identification techniques. Front Microbiol 2014; 5: 705.

16. Senderovich Y, Izhaki I, and Halpern M, Fish as reservoirs and vectors of Vibrio cholerae. PLoS One 2010; 5(1): e8607-e8607.

17. Tack DM, Marder EP, Griffin PM, et al., Preliminary incidence and trends of infections with pathogens transmitted commonly through food-Foodborne Diseases Active Surveillance Network, 10 US sites, 2015-2018. Morbidity and Mortality Weekly Report 2019; 68(16): 369.

18. Díaz-Quiñonez A, Hernández-Monroy I, Montes-Colima N, et al., Notes from the Field: Outbreak of Vibrio cholerae Serogroup O1, Serotype Ogawa, Biotype El Tor Strain-La Huasteca Region, Mexico, 2013. MMWR Morb Mortal Wkly Rep 2014; 63(25): 552-553.

19. Kumar P, Mishra DK, Deshmukh DG, et al., Vibrio cholerae O1 Ogawa
El Tor strains with the ctxB7 allele driving cholera outbreaks in southwestern India in 2012. Infect Genet Evol 2014; 25: 93-6.

20. Ma C, Deng X, Ke C, et al., Epidemiology and etiology characteristics of foodborne outbreaks caused by Vibrio parahaemolyticus during 2008-2010 in Guangdong province, China. Foodborne Pathog Dis 2014; 11(1): 21-9.

21. Centers for Disease Control Prevention, Notes from the field: Identification of Vibrio cholerae serogroup O1, serotype Inaba, biotype El Tor strain-Haiti, March 2012. MMWR Morb Mortal Wkly Rep 2012; 61(17): 309.

22. Shruti C, Vibrio related diseases in aquaculture and development of rapid and accurate identification methods. J Marine Sci Res Dev 2012.

23. Austin B and Zhang XH, Vibrio harveyi: a significant pathogen of marine vertebrates and invertebrates. Lett Appl Microbiol 2006; 43(2): 119-24.

24. Karunasagar I, Pai R, Malathi G, et al., Mass mortality of Penaeus monodon larvae due to antibiotic-resistant Vibrio harveyi infection. Aquaculture 1994; 128(3): 203-209.

25. Lavilla-Pitogo CR, Baticados MCL, Cruz-Lacierda ER, et al., Occurrence of luminous bacterial disease of Penaeus monodon larvae in the Philippines. Aquaculture 1990; 91(1): 1-13.

26. Geng Y, Liu D, Han S, et al., Outbreaks of vibriosis associated with Vibrio mimicus in freshwater catfish in China. Aquaculture 2014; 433 82-84.

27. Lalumera GM, Calamari D, Galli $\mathrm{P}$, et al., Preliminary investigation on the environmental occurrence and effects of antibiotics used in aquaculture in Italy. Chemosphere 2004; 54(5): 661-668.

28. Acharyya S, Patra A, and Bag PK, Evaluation of the antimicrobial activity of some medicinal plants against enteric bacteria with particular reference to multi-drug resistant Vibrio cholerae. Trop J Pharm Res 2009; $8(3)$.

29. Tan LTH, Lee LH, Yin WF, et al., Traditional Uses, Phytochemistry, and Bioactivities of Cananga odorata (Ylang-Ylang). Evid Based Complement Alternat Med 2015; 2015.

30. Chan W-K, Tan L, Chan K-G, et al., Nerolidol: a sesquiterpene alcohol with multi-faceted pharmacological and biological activities. Molecules 2016; 21(5): 529 .

31. Tang C, Hoo PC-X, Tan LT-H, et al., Golden needle mushroom: a culinary medicine with evidenced-based biological activities and health promoting properties. Front Pharmacol 2016; 7: 474.

32. Ma DS, Tan LT-H, Chan K-G, et al., Resveratrol - potential antibacterial agent against foodborne pathogens. Front Pharmacol 2018; 9: 102.

33. Kobayashi J and Ishibashi M, Bioactive metabolites of symbiotic marine microorganisms. Chem Rev 1993; 93(5): 1753-1769.

34. Dharmaraj S, Marine Streptomyces as a novel source of bioactive substances. World J Microbiol Biotechnol 2010; 26(12): 2123-2139.

35. Hong K, Gao A-H, Xie Q-Y, et al., Actinomycetes for marine drug discovery isolated from mangrove soils and plants in China. Mar Drugs 2009; 7(1): 24-44.

36. Ser H-L, Tan W-S, Cheng H-J, et al., Draft genome of amylolytic actinobacterium, Sinomonas humi MUSC 117T isolated from intertida soil. Mar Genomics 2015; 24: 209-210.

37. Lee L-H, Cheah Y-K, Sidik SM, et al., Barrientosiimonas humi gen. nov., sp. nov., an actinobacterium of the family Dermacoccaceae. Int J Syst Evol Microbiol 2013; 63(1): 241-248.

38. Tan LT-H, Chan K-G, Chan CK, et al., Antioxidative potential of a Streptomyces sp. MUM292 isolated from mangrove soil. Biomed Res Int 2018; 2018.

39. Tan LTH, Mahendra CK, Yow YY, et al., Streptomyces sp. MUM273b: A mangrove-derived potential source for antioxidant and UVB radiation protectants. Microbiologyopen 2019: e859.

40. Lee L-H, Zainal N, Azman A-S, et al., Diversity and antimicrobial activities of actinobacteria isolated from tropical mangrove sediments in Malaysia. ScientifcWorldJournal 2014; 2014

41. Lee L-H, Zainal N, Azman A-S, et al., Streptomyces pluripotens sp. nov., a bacteriocin-producing streptomycete that inhibits meticillinresistant Staphylococcus aureus. Int J Syst Evol Microbiol 2014; 64(Pt 9): 3297-3306

42. Ser H-L, Palanisamy UD, Yin W-F, et al., Presence of antioxidative agent, Pyrrolo [1, 2-a] pyrazine-1, 4-dione, hexahydro-in newly isolated Streptomyces mangrovisoli sp. nov. Front Microbiol 2015; 6: 854

43. Ser HL, Zainal N, Palanisamy UD, et al., Streptomyces gilvigriseus sp. nov., a novel actinobacterium isolated from mangrove forest soil. Antonie Van Leeuwenhoek 2015; 107(6): 1369-78.

44. Schatz A, Bugle E, and Waksman SA, Streptomycin, a Substance Exhibiting Antibiotic Activity Against Gram-Positive and Gram-Negative Bacteria.*†. Exp Biol Med 1944; 55(1): 66-69.

45. Manivasagan P, Venkatesan J, Sivakumar K, et al., Marine actinobacterial metabolites: current status and future perspectives. Microbiol Res 2013; 168(6): 311-32.

46. Tan LT-H, Chan K-G, Pusparajah P, et al., Mangrove derived Streptomyces sp. MUM265 as a potential source of antioxidant and anticoloncancer agents. BMC Microbiol 2019; 19(1): 38.

47. Nair AG, Selvakumar D, and Dhevendaran K, Occurrence of sponges associated Streptomyces and its antimicrobial activity. World J Fish Mar Sci 2011; 3: 151-158.

48. Schrey SD and Tarkka MT, Friends and foes: streptomycetes as modulators of plant disease and symbiosis. Antonie Van Leeuwenhoek 2008; 94(1): 11-19.

49. Kaltenpoth M, Yildirim E, Gurbuz MF, et al., Refining the roots of the beewolf-Streptomyces symbiosis: antennal symbionts in the rare genus Philanthinus (Hymenoptera, Crabronidae). Appl Environ Microbiol 2012; 78(3): 822-7.

50. Farmer III J and Hickman-Brenner F, The genera Vibrio and photobacterium, in The prokaryotes. 2006, Springer. p. 508-563. 
51. Pruzzo C, Gallo G, and Canesi L, Persistence of vibrios in marine bivalves: the role of interactions with haemolymph components. Environ Microbiol 2005; 7(6): 761-772.

52. Letchumanan V, Yin W-F, Lee L-H, et al., Prevalence and antimicrobial susceptibility of Vibrio parahaemolyticus isolated from retail shrimps in Malaysia. Front Microbiol 2015; 6: 33 .

53. Johnson CN, Fitness factors in vibrios: a mini-review. Microb Ecol 2013; 65(4): 826-51

54. Haan Ld and Hirst TR, Cholera toxin: a paradigm for multi-functional engagement of cellular mechanisms (Review). Mol Membr Biol 2004; 21(2): 77-92.

55. Jones MK and Oliver JD, Vibrio vulnificus: disease and pathogenesis. Infect Immun 2009; 77(5): 1723-1733.

56. Schauder S and Bassler BL, The languages of bacteria. Genes Dev 2001; 15(12): 1468-1480.

57. Miller MB, Skorupski K, Lenz DH, et al., Parallel quorum sensing systems converge to regulate virulence in Vibrio cholerae. Cell 2002; 110(3): 303-314

58. Lupp C and Ruby EG, Vibrio fischeri uses two quorum-sensing systems for the regulation of early and late colonization factors. J Bacteriol 2005; 187(11): 3620-3629.

59. Verschuere L, Rombaut G, Sorgeloos P, et al., Probiotic bacteria as biological control agents in aquaculture. Microbiol Mol Biol Rev 2000; 64(4): 655-671.

60. Letchumanan V, Loo KY, Law JWF, et al., Vibrio parahaemolyticus: the protagonist causing foodborne diseases. Prog Microbes Mol Biol 2019; 2(1): a0000029.

61. Letchumanan V, Chan K-G, and Lee L-H, An insight of traditional plasmid curing in Vibrio species. Front Microbiol 2015; 6: 735.

62. Holmström K, Gräslund S, Wahlström A, et al., Antibiotic use in shrimp farming and implications for environmental impacts and human health. Int J Food Sci Technol 2003; 38(3): 255-266.

63. Letchumanan V, Chan KG, and Lee LH, An insight of traditional plasmid curing in Vibrio species. Front Microbiol 2015; 6: 735.

64. Lee L-H, Ab Mutalib N-S, Law JW-F, et al., Discovery on antibiotic resistance patterns of Vibrio parahaemolyticus in Selangor reveals carbapenemase producing Vibrio parahaemolyticus in marine and freshwater fish. Front Microbiol 2018; 9: 2513.

65. Cheah YK, Lee LH, Noorzaleha AS, et al, Characterization of multiple-antimicrobial-resistant Salmonella enterica subsp. enterica isolated from indigenous vegetables and poultry in Malaysia. Lett Appl Microbiol 2008; 46(3): 318-324.

66. Lee LH, Cheah YK, Salleh NA, et al., Analysis of Salmonella Agona and Salmonella Weltevreden in Malaysia by PCR fingerprinting and antibiotic resistance profiling. Antonie Van Leeuwenhoek 2008; 94(3): 377.

67. Roque A, Molina-Aja A, Bolan-Mejia C, et al., In vitro susceptibility to 15 antibiotics of vibrios isolated from penaeid shrimps in Northwestern Mexico. Int J Antimicrob Agents 2001; 17(5): 383-7.

68. Tendencia EA and de la Peña LD, Antibiotic resistance of bacteria from shrimp ponds. Aquaculture 2001; 195(3): 193-204.

69. Zou S, Xu W, Zhang R, et al., Occurrence and distribution of antibiotics in coastal water of the Bohai Bay, China: impacts of river discharge and aquaculture activities. Environ Pollut 2011; 159(10): 2913-20.

70. Lee L-H and Raghunath P, Vibrionaceae diversity, multidrug resistance and management. Front Microbiol 2018; 9: 563 .

71. Albuquerque Costa R, Araujo RL, Souza OV, et al., Antibiotic-resistant vibrios in farmed shrimp. Biomed Res Int 2015; 2015: 505914

72. Han JE, Mohney LL, Tang KF, et al., Plasmid mediated tetracycline resistance of Vibrio parahaemolyticus associated with acute hepatopancreatic necrosis disease (AHPND) in shrimps. Aquacult Rep 2015; 2: $17-21$.

73. Leaño EM and Mohan C, Early mortality syndrome threatens Asia's shrimp farms. Global Aquac Advocate 2012; 15(4): 38-39.

74. Lightner D, Redman R, Pantoja C, et al., Early mortality syndrome affects shrimp in Asia Global Aquac Alliance 2012: 40

75. Castillo D, Jun JW, D'Alvise P, et al., Draft Genome Sequence of Vibrio parahaemolyticus $\mathrm{VH} 3$, Isolated from an Aquaculture Environment in Greece. Genome Announc 2015; 3(4): e00731-15.

76. Jun JW, Kim JH, Choresca $\mathrm{Jr} \mathrm{CH}$, et al., Isolation, molecular characterization, and antibiotic susceptibility of Vibrio parahaemolyticus in Korean seafood. Foodborne Pathog Dis 2012; 9(3): 224-231

77. Letchumanan V, Pusparajah P, Tan LTH, et al., Occurrence and Antibiotic Resistance of Vibrio parahaemolyticus from Shellfish in Selangor, Malaysia. Front Microbiol 2015; 6: 1417.

78. Chao G, Jiao X, Zhou X, et al., Serodiversity, pandemic O3: K6 clone, molecular typing, and antibiotic susceptibility of foodborne and clinical Vibrio parahaemolyticus isolates in Jiangsu, China. Foodborne Pathog Dis 2009; 6(8): 1021-1028.

79. Xu X, Cheng J, Wu Q et al., Prevalence, characterization, and antibiotic susceptibility of Vibrio parahaemolyticus isolated from retail aquatic products in North China. BMC Microbiol 2016; 16(1): 1

80. Miwanda B, Moore S, Muyembe JJ, et al., Antimicrobial Drug Resistance of Vibrio cholerae, Democratic Republic of the Congo. Emerg Infect Dis 2015; 21(5): 847-51.

81. Kitaoka M, Miyata ST, Unterweger D, et al., Antibiotic resistance mechanisms of Vibrio cholerae. J Med Microbiol 2011; 60(Pt 4): 397407.

82. Glass RI, Huq MI, Lee JV, et al., Plasmid-borne multiple drug resistance in Vibrio cholerae serogroup O1, biotype El Tor: evidence for a point-source outbreak in Bangladesh. J Infect Dis 1983; 147(2): 204-9.

83. Garg P, Chakraborty S, Basu I, et al., Expanding multiple antibiotic resistance among clinical strains of Vibrio cholerae isolated from 1992-7 in Calcutta, India. Epidemiol Infect 2000; 124(03): 393-399.

84. Dalsgaard A, Forslund A, Sandvang D, et al., Vibrio cholerae O1 out- break isolates in Mozambique and South Africa in 1998 are multipledrug resistant, contain the SXT element and the aadA2 gene located on class 1 integrons. J Antimicrob Chemother 2001; 48(6): 827-38.

85. Sjolund-Karlsson M, Reimer A, Folster JP, et al., Drug-resistance mechanisms in Vibrio cholerae O1 outbreak strain, Haiti, 2010. Emerg Infect Dis 2011; 17(11): 2151-4.

86. Tran HD, Alam M, Trung NV, et al., Multi-drug resistant Vibrio cholerae O1 variant El Tor isolated in northern Vietnam between 2007 and 2010. J Med Microbiol 2012; 61(3): 431-437.

87. Roychowdhury A, Pan A, Dutta D, et al., Emergence of tetracyclineresistant Vibrio cholerae O1 serotype Inaba, in Kolkata, India. Jpn J Infect Dis 2008; 61(2): 128-9.

88. Petroni A, Corso A, Melano R, et al., Plasmidic extended-spectrum beta-lactamases in Vibrio cholerae O1 El Tor isolates in Argentina. Antimicrob Agents Chemother 2002; 46(5): 1462-8

89. Khan WA, Saha D, Ahmed S, et al., Efficacy of ciprofloxacin for treatment of cholera associated with diminished susceptibility to ciprofloxacin to Vibrio cholerae O1. PLoS One 2015; 10(8): e0134921.

90. Dalsgaard A, Forslund A, Tam NV, et al., Cholera in Vietnam: changes in genotypes and emergence of class I integrons containing aminoglycoside resistance gene cassettes in vibrio cholerae $\mathrm{O} 1$ strain isolated from 1979 to 1996. J Clin Microbiol 1999; 37(3): 734-41

91. Meibom KL, Blokesch M, Dolganov NA, et al., Chitin induces natural competence in Vibrio cholerae. Science 2005; 310(5755): 1824-7.

92. Waldor MK, Tschape H, and Mekalanos JJ, A new type of conjugative transposon encodes resistance to sulfamethoxazole, trimethoprim, and streptomycin in Vibrio cholerae O139. J Bacteriol 1996; 178(14): 4157-65.

93. Burrus V, Marrero J, and Waldor MK, The current ICE age: biology and evolution of SXT-related integrating conjugative elements. Plasmid 2006; 55(3): 173-83

94. Wang R, Yu D, Yue J, et al., Variations in SXT elements in epidemic Vibrio cholerae O1 El Tor strains in China. Sci Rep 2016; 6: 22733.

95. Spellberg B and Shlaes D, Prioritized current unmet needs for antibacterial therapies. Clin Pharmacol Ther 2014; 96(2): 151-3.

96. Bush K, Courvalin P, Dantas G, et al., Tackling antibiotic resistance. Nat Rev Microbiol 2011; 9(12): 894-6.

97. Flardh K and Buttner MJ, Streptomyces morphogenetics: dissecting differentiation in a filamentous bacterium. Nat Rev Microbiol 2009; 7(1): 36-49.

98. Law JW-F, Tan K-X, Wong SH, et al., Taxonomic and characterization methods of Streptomyces: a review. Prog Microb Mol Biol 2018; $1(1)$.

99. Manteca A, Alvarez R, Salazar N, et al., Mycelium differentiation and antibiotic production in submerged cultures of Streptomyces coelicolor. Appl Environ Microbiol 2008; 74(12): 3877-86.

100. Hwang KS, Kim HU, Charusanti P, et al., Systems biology and biotechnology of Streptomyces species for the production of secondary metabolites. Biotechnol Adv 2014; 32(2): 255-68

101. van Wezel GP and McDowall KJ, The regulation of the secondary metabolism of Streptomyces: new links and experimental advances. Nat Prod Rep 2011; 28(7): 1311-33.

102. Tan LT-H, Chan K-G, Khan TM, et al., Streptomyces sp. MUM212 as a source of antioxidants with radical scavenging and metal chelating properties. Front Pharmacol 2017; 8: 276

103. Berdy J, Bioactive microbial metabolites. J Antibiot 2005; 58(1): $1-26$

104. Solecka J, Zajko J, Postek M, et al., Biologically active secondary metabolites from Actinomycetes. Open Life Sci 2012; 7(3): 373-390

105. Law JW-F, Pusparajah P, Ab Mutalib N-S, et al., A Review on Mangrove Actinobacterial Diversity: The Roles of Streptomyces and Novel Species Discovery. Prog Microb Mol Biol 2019; 1(1)

106. Yim G, Thaker MN, Koteva K, et al., Glycopeptide antibiotic biosynthesis. J Antibiot (Tokyo) 2014; 67(1): 31-41.

107. Rohr J and Thiericke R, Angucycline group antibiotics. Nat Prod Rep 1992; 9(2): 103-37.

108. Chopra I and Roberts M, Tetracycline antibiotics: mode of action, applications, molecular biology, and epidemiology of bacterial resistance. Microbiol Mol Biol Rev 2001; 65(2): 232-60 Kuamr R, Shrivastav AK, Singha AK.

109. Laursen JB and Nielsen J, Phenazine natural products: biosynthesis, synthetic analogues, and biological activity. Chem Rev 2004; 104(3): 1663-86

110. Zhanel GG, Dueck M, Hoban DJ, et al., Review of macrolides and ketolides: focus on respiratory tract infections. Drugs 2001; 61(4): 443-98

111. Kudo F and Eguchi T, Biosynthetic genes for aminoglycoside antibiotics. J Antibiot (Tokyo) 2009; 62(9): 471-81.

112. Syvitski RT, Borissow CN, Graham CL, et al., Ring-opening dynamics of jadomycin A and B and dalomycin T. Org Lett 2006; 8(4): 697700

113. de Leder Kremer RM and Gallo-Rodriguez C, Naturally occurring monosaccharides: properties and synthesis. Adv Carbohydr Chem Biochem 2004; 59: 9-67.

114. Slattery M, Rajbhandari I, and Wesson K, Competition-Mediated Antibiotic Induction in the Marine Bacterium Streptomyces tenjimariensis. Microb Ecol 2001; 41(2): 90-96.

115. Tan LTH, Ser HL, Yin WF, et al., Investigation of Antioxidative and Anticancer Potentials of Streptomyces sp. MUM256 Isolated from Malaysia Mangrove Soil. Front Microbiol 2015; 6: 1316.

116. Basilio A, Gonzalez I, Vicente MF, et al., Patterns of antimicrobial activities from soil actinomycetes isolated under different conditions of $\mathrm{pH}$ and salinity. J Appl Microbiol 2003; 95(4): 814-23.

117. Bentley SD, Chater KF, Cerdeno-Tarraga AM, et al., Complete genome sequence of the model actinomycete Streptomyces coelicolor 
A3(2). Nature 2002; 417(6885): 141-7.

118. Ikeda H, Ishikawa J, Hanamoto A, et al., Complete genome sequence and comparative analysis of the industrial microorganism Streptomyces avermitilis. Nat Biotechnol 2003; 21(5): 526-31.

119. Eppinger M, Bunk B, Johns MA, et al., Genome sequences of the biotechnologically important Bacillus megaterium strains QM B1551 and DSM319. J Bacteriol 2011; 193(16): 4199-213.

120. Weber T, Charusanti P, Musiol-Kroll EM, et al., Metabolic engineering of antibiotic factories: new tools for antibiotic production in actinomycetes. Trends Biotechnol 2015; 33(1): 15-26.

121. Ser H-L, Tan W-S, Ab Mutalib N-S, et al., Genome sequence of Streptomyces pluripotens MUSC $135 \mathrm{~T}$ exhibiting antibacterial and antioxidant activity. Mar Genomics 2015.

122. Kemung HM, Hern T, Loh T, et al., Streptomyces as a prominent resource of future anti-MRSA drugs. Front Microbiol 2018; 9: 2221.

123. Rateb ME, Houssen WE, Harrison WT, et al., Diverse metabolic profiles of a Streptomyces strain isolated from a hyper-arid environment. J Nat Prod 2011; 74(9): 1965-71

124. Arasu MV, Rejiniemon TS, Al-Dhabi NA, et al., Nutritional requirements for the production of antimicrobial metabolites from Streptomyces. Aft J Microbiol Res 2014; 8(8): 750-758.

125. Sahu MK, Murugan M, Sivakumar K, et al., Occurrence and distribution of actinomycetes in marine environs and their antagonistic activity against bacteria that is pathogenic to shrimps. Isr J Aquacult-Bamid 2007; 59(3): 155-161.

126. Nithya $\mathrm{C}$ and Pandian SK, Isolation of heterotrophic bacteria from Palk Bay sediments showing heavy metal tolerance and antibiotic production. Microbiol Res 2010; 165(7): 578-593.

127. Pugazhvendan SR, Kumaran S, Alagappan KM, et al., Inhibition of fish bacterial pathogens by antagonistic marine actinomycetes. Eur J Appl Sci 2010; 2(2): 41-43

128. Vasanthabharathi V, Lakshminarayanan R, and Jayalakshmi S, Melanin production from marine Streptomyces. Afr J Biotechnol 2011; 10(54): 11224-11234.

129. Kuamr R, Shrivastav AK, Singha AK, et al., Antibiotic production from marine Strptomycyes sp. Int J Pharma Bio Sci 2012; 3(4): 331-342.

130. Valli S, Suvathi SS, Aysha OS, et al., Antimicrobial potential of Actinomycetes species isolated from marine environment. Asian Pac J Trop Dis 2012; 2(6): 469-73.

131. Ganesan S, Velsamy G, Sivasudha T, et al., MALDI-TOF mass spectrum profiling, antibacterial and anticancer activity of marine Streptomyces fradiae BDMS1. World J Pharm Pharm Sci 2013; 2(6): 51485165 .

132. Kadiri S, sastry Yarla N, and Vidavalur S, Isolation and Identification of A Novel Aporphine Alkaloid SSV, An Antitumor Antibiotic from Fermented Broth of Marine Associated Streptomyces sp. KS1908. J Marine Sci Res Dev 2013; 2013.

133. Meena B, Rajan LA, Vinithkumar NV, et al., Novel marine actinobacteria from emerald Andaman \& Nicobar Islands: a prospective source for industrial and pharmaceutical byproducts. BMC Microbiol 2013; 13(1): 145.

134. Mohanraj G and Sekar T, Antagonistic activity of marine Streptomyces sp LCJ94 against the shrimp pathogens. Ann Biol Res 2013; 4(4): 224227.

135. Sivasankar P, Sugesh S, Vijayanand P, et al., Efficient production of 1asparaginase by marine Streptomyces sp. isolated from Bay of Bengal, India. Afr J Microbiol Res 2013; 7: 4015-4021.

136. Dharumadurai D, Annamalai P, Nooruddin T, et al., Isolation, Characterization of Antibacterial Methyl Substituted $\beta$-Lactum Compound from Streptomyces noursei DPTD21 in Saltpan Soil, India. J Biol Act Prod Nat 2014; 4(2): 71-88.

137. Sivaperumal P, Kamala K, and Rajaram R, Bioactive DOPA melanin isolated and characterised from a marine actinobacterium Streptomyces sp. MVCS6 from Versova coast. Nat Prod Res 2015; 29(22): 2117-21.

138. Sivaperumal P, Kamala K, Rajaram R, et al., Melanin from marine Streptomyces sp.(MVCS13) with potential effect against ornamental fish pathogens of Carassius auratus (Linnaeus, 1758). Biocatal Agric Biotechnol 2014; 3(4): 134-141.

139. Long L, Tian X, Li J, et al., Marine streptomyces, pyranosesquiterpene compound, as well as preparation method and applications thereof. 2012, Google Patents.

140. You J, Cao L, Liu G, et al., Isolation and characterization of actinomycetes antagonistic to pathogenic Vibrio spp. from nearshore marine sediments. World J Microbiol Biotechnol 2005; 21(5): 679-682.

141. Hieu NX, Thuan LTN, Matsumoto M, et al., Identification and characterization of Actinomycetes antagonistic to pathogenic Vibrio spp. isolated from shrimp culture pond sediments in Thua Thien Hue-Viet Nam. J Fac Agr Kyushu U 2011; 56(1): 15-22.

142. Chau NTT, Matsumoto M, and Miyajima I, Optimization of Medium for the Production of a Novel Aquaculture Probiotic, Streptomyces sp. A1 Using Central Composite Design of Response Surface Methodology. J Fac Agr Kyushu U 2014; 59(1): 25-32.

143. Cho JY and Kim MS, Antibacterial benzaldehydes produced by seaweed-derived Streptomyces atrovirens PK288-21. Fish Sci 2012; 78(5): 1065-1073.

144. Barakat KM and Beltagy EA, Bioactive phthalate from marine Streptomyces ruber EKH2 against virulent fish pathogens. Egypt J Aquat Res 2015; 41(1): 49-56.

145. Bernal MG, Campa-Córdova ÁI, Saucedo PE, et al., Isolation and in vitro selection of actinomycetes strains as potential probiotics for aquaculture. Vet World 2015

146. Das S, Ward LR, and Burke C, Screening of marine Streptomyces spp for potential use as probiotics in aquaculture. Aquaculture 2010; 305(1): 32-41.

147. Rathnakala $\mathrm{R}$ and Chandrika V, Growth Inhibition of fish pathogens by antagonistic actinomycetes isolated from mangrove environment. The Fourth Indian Fisheries Forum Proceedings 1999: 337-341.

148. Arifuzzaman M, Khatun M, and Rahman H, Isolation and screening of actinomycetes from Sundarbans soil for antibacterial activity. Afr J Biotechnol 2010; 9(29): 4615-4619.

149. Mohana S and Radhakrishnan M, Streptomyces sp MA7 isolated from mangrove rhizosphere sediment effective against Gram negative bacterial pathogens. Int J Pharmtech Res 2014; 6(4): 1259-1264.

150. Thirumurugan D and Vijayakumar R, Exploitation of Antibacterial Compound Producing Marine Actinobacteria against Fish Pathogens Isolated from Less Explored Environments. Res J Sci Technol 2013; 5(2): IV

151. Thirumurugan D and Vijayakumar R, A potent fish pathogenic bacterial killer Streptomyces sp. isolated from the soils of east coast region, South India. J Coast Life Med 2013; 1(3): 175-180.

152. Thirumurugan D and Vijayakumar R, Characterization and structure elucidation of antibacterial compound of Streptomyces sp. ECR77 isolated from east coast of India. Curr Microbiol 2015; 70(5): 745-55.

153. Sengupta S, Pramanik A, Ghosh A, et al., Antimicrobial activities of actinomycetes isolated from unexplored regions of Sundarbans mangrove ecosystem. BMC Microbiol 2015; 15(1): 170.

154. Jayasudha J, Kumar G, Karthik L, et al., Biological control of vibriosis by antagonistic actinobacteria-an in vitro study. Int J Agric Technol 2011; 7(2): 271-280.

155. Reddy N, Ramakrishna D, and Raja Gopal S, A morphological, physiological and biochemical studies of marine Streptomyces rochei (MTCC 10109) showing antagonistic activity against selective human pathogenic microorganisms. Asian J Biol Sci 2011; 4(1): 1-14.

156. Selvakumar D, Arun K, Suguna S, et al., Bioactive potential of Streptomyces against fish and shellfish pathogens. Iran J Microbiol 2010; 2(3): 157-64.

157. Dharmaraj S and Sumantha A, Bioactive potential of Streptomyces associated with marine sponges. World J Microbiol Biotechnol 2009; 25(11): 1971-1979.

158. Dharmaraj S, Antagonistic potential of marine actinobacteria against fish and shellfish pathogens. Turk J Biol 2011; 35(3): 303-311.

159. Su P, Wang DX, Ding SX, et al., Isolation and diversity of natural product biosynthetic genes of cultivable bacteria associated with marine sponge Mycale sp. from the coast of Fujian, China. Can J Microbiol 2014; 60(4): 217-25.

160. ElAhwany AM, Ghozlan HA, ElSharif HA, et al., Phylogenetic diversity and antimicrobial activity of marine bacteria associated with the soft coral Sarcophyton glaucum. J Basic Microbiol 2015; 55(1): 2-10.

161. Nithyanand P, Manju S, and Pandian SK, Phylogenetic characterization of culturable actinomycetes associated with the mucus of the coral Acropora digitifera from Gulf of Mannar. FEMS Microbiol Lett 2011; 314(2): 112-118.

162. Zhang X-Y, He F, Wang G-H, et al., Diversity and antibacterial activity of culturable actinobacteria isolated from five species of the South China Sea gorgonian corals. World J Microbiol Biotechnol 2013; 29(6): 1107-1116.

163. Li J, Dong J-D, Yang J, et al., Detection of polyketide synthase and nonribosomal peptide synthetase biosynthetic genes from antimicrobial coral-associated actinomycetes. Antonie Van Leeuwenhoek 2014; 106(4): 623-635.

164. Sheeja M, Selvakumar D, and Dhevendaran K, Antagonistic potential of Streptomyces associated with the gut of marine ornamental fishes. Middle East J Sci Res 2011; 7(3): 327-334

165. Deepa S, Bharathidasan R, and Panneerselvam A, Studies on isolation of nutritional grouping streptomycetes from fishes. Adv Appl Sci Res 2012; 3(2): 895-899.

166. Suguna S, Antagonistic study on Streptomyces spp isolated from marine fish and its antibiogram spectrum against human and fish pathogens. Int J Pharm Biol Arch 2012; 3(3).

167. Zheng Z, Zeng W, Huang Y, et al., Detection of antitumor and antimicrobial activities in marine organism associated actinomycetes isolated from the Taiwan Strait, China. FEMS Microbiol Lett 2000; 188(1): 8791.

168. Sridevi K and Dhevendaran K, Genetic analysis of antibiotic production and other phenotypic traits from Streptomyces associated with seaweeds. Afr J Biotechnol 2014; 13(26): 2648.

169. Sridevi K and Dhevendaran K, Evaluation of Streptomyces as probiotics against vibriosis and health management of prawn larvae Macrobrachium rosenbergii. Afr J Microbiol Res 2014; 8(41): 3595-3603.

170. Sridevi K and Dhevendaran K, Streptomycetes from marine seaweeds: their antimicrobial and antibiotic potential Int J Appl Biol Pharm 2014; 5(4): 74-79.

171. Bonjar GS, Broadspectrim, a novel antibacterial from Streptomyces sp. Biotechnology (Pakistan) 2004.

172. Dileep N, Junaid S, Rakesh KN, et al., Antibacterial activity of three Streptomyces species isolated from soils of Shikaripura, Karnataka, India. J Biol Sci Opin 2013; 1(3)

173. Kekuda P, Dileep N, Junaid S, et al., Biological activities of Streptomyces species SRDP-07 isolated from soil of Thirthahalli, Karnataka, India. Int J Drug Dev Res 2013; 5(3): 268-285.

174. Mohanta YK and Behera SK, Biosynthesis, characterization and antimicrobial activity of silver nanoparticles by Streptomyces sp. SS2. Bioprocess Biosyst Eng 2014; 37(11): 2263-9.

175. Valan AM, Ignacimuthu S, and Agastian P, Actinomycetes from Western Ghats of Tamil Nadu with its antimicrobial properties. Asian Pac J Trop Dis 2012; 2(2): S830-S837.

176. Charoensopharat K, Thummabenjapone P, Sirithorn P, et al., Antibacterial substance produced by Streptomyces sp. No. 87. Afr J Biotechnol 2008; 7(9).

177. Uddin M, Mahmud M, Anwar M, et al., Influence of culturing condi- 
tions for optimum antimicrobial metabolite production by Streptomyces fulvoviridis. Chittagong Univ J Biol Sci 2013; 5(1): 63-75.

178. Castillo UF, Strobel GA, Ford EJ, et al., Munumbicins, wide-spectrum antibiotics produced by Streptomyces NRRL 30562, endophytic on Kennedia nigriscans. Microbiology 2002; 148(Pt 9): 2675-85.

179. Ser H-L, Tan LT-H, Law JW-F, et al., Focused review: cytotoxic and antioxidant potentials of mangrove-derived Streptomyces. Front Microbiol 2017; 8: 2065 .

180. Law JW-F, Ser H-L, Ab Mutalib N-S, et al., Streptomyces monashensis sp. nov., a novel mangrove soil actinobacterium from East Malaysia with antioxidative potential. Sci Rep 2019; 9(1): 3056.

181. Law JW-F, Ser H-L, Duangjai A, et al., Streptomyces colonosanans sp. nov., a novel actinobacterium isolated from Malaysia mangrove soil exhibiting antioxidative activity and cytotoxic potential against human colon cancer cell lines. Front Microbiol 2017; 8: 877.

182. Rahman MA, Islam MZ, Khondkar P, et al., Characterization and antimicrobial activities of a polypeptide antibiotic isolated from a new strain of Streptomyces parvulus. Bangladesh Pharm J 2010; 13(1): 1416.

183. Watve MG, Tickoo R, Jog MM, et al., How many antibiotics are produced by the genus Streptomyces? Arch Microbiol 2001; 176(5): 386390

184. Augustine N, Kerkar S, and Thomas S, Arctic actinomycetes as potential inhibitors of Vibrio cholerae biofilm. Curr Microbiol 2012; 64(4): 338-342.

185. Busarakam K, Bull AT, Girard G, et al., Streptomyces leeuwenhoekii sp. nov., the producer of chaxalactins and chaxamycins, forms a distinct branch in Streptomyces gene trees. Antonie Van Leeuwenhoek 2014; 105(5): 849-61.

186. Iwatsuki M, Uchida R, Yoshijima H, et al., Guadinomines, type III secretion system inhibitors, produced by Streptomyces sp. K01-0509. J Antibiot 2008; 61: 230-236

187. Zindel S, Kaman WE, Fröls S, et al., The papain inhibitor (SPI) of Streptomyces mobaraensis inhibits bacterial cysteine proteases and is an antagonist of bacterial growth. Antimicrob Agents Chemother 2013; 57(7): 3388-3391

188. Holmes TC, May AE, Zaleta-Rivera K, et al., Molecular insights into the biosynthesis of guadinomine: a type III secretion system inhibitor. J Am Chem Soc 2012; 134(42): 17797-17806.

189. Pathom-Aree W, Stach JE, Ward AC, et al., Diversity of actinomycetes isolated from Challenger Deep sediment $(10,898 \mathrm{~m})$ from the Mariana Trench. Extremophiles 2006; 10(3): 181-9.

190. Subramani R and Aalbersberg W, Marine actinomycetes: an ongoing source of novel bioactive metabolites. Microbiol Res 2012; 167(10): 571-80.

191. Lee L-H, Zainal N, Azman A-S, et al., Mumia flava gen. nov., sp. nov., an actinobacterium of the family Nocardioidaceae. Int J Syst Evol Microbiol 2014; 64(5): 1461-1467.

192. Lee L-H, Azman A-S, Zainal N, et al., Sinomonas humi sp. nov., an amylolytic actinobacterium isolated from mangrove forest soil. Int $\mathrm{J}$ Syst Evol Microbiol 2015; 65(3): 996-1002.

193. Azman AS, Othman I, Velu SS, et al., Mangrove rare actinobacteria: taxonomy, natural compound, and discovery of bioactivity. Front Microbiol 2015; 6: 856

194. Azman A-S, Othman I, Fang C-M, et al., Antibacterial, anticancer and neuroprotective activities of rare Actinobacteria from mangrove forest soils. Indian J Microbiol 2017; 57(2): 177-187.

195. Ser H-L, Ab Mutalib N-S, Yin W-F, et al., Genome sequence of Streptomyces antioxidans MUSC 164T isolated from mangrove forest. Prog Microb Mol Biol 2018; 1(1).

196. Ser H-L, Tan LT-H, Palanisamy UD, et al., Streptomyces antioxidans sp. nov., a novel mangrove soil actinobacterium with antioxidative and neuroprotective potentials. Front Microbiol 2016; 7: 899.

197. Mitra A, Pramanik A, Santra SC, et al., Phylogeny, phenotypic and nutritional characteristics of estuarine soil actinomycetes having broadspectrum antimicrobial activity derived from an ecologically guided bioprospecting programme. World J Microbiol Biotechnol 2011; 27(7): 1679-1688.

198. Mitra A, Santra SC, and Mukherjee J, Distribution of actinomycetes, their antagonistic behaviour and the physico-chemical characteristics of the world's largest tidal mangrove forest. Appl Microbiol Biotechnol 2008; 80(4): 685-695.

199. Meena B, Rajan LA, Vinithkumar NV, et al., Novel marine actinobacteria from emerald Andaman \& Nicobar Islands: a prospective source for industrial and pharmaceutical byproducts. BMC Microbiol 2013; 13(1):
145

200. You J, Xue X, Cao L, et al., Inhibition of Vibrio biofilm formation by a marine actinomycete strain A66. Appl Microbiol Biotechnol 2007; 76(5): 1137-44.

201. Sahoo K and Dhal N, Potential microbial diversity in mangrove ecosystems: a review. Indian J Mar Sci 2009.

202. Zainal N, Ser H-L, Yin W-F, et al., Streptomyces humi sp. nov., an actinobacterium isolated from soil of a mangrove forest. Antonie Van Leeuwenhoek 2016; 109(3): 467-474.

203. Lee L-H, Azman A-S, Zainal N, et al., Microbacterium mangrovi sp. nov., an amylolytic actinobacterium isolated from mangrove forest soil. Int J Syst Evol Microbiol 2014; 64(10): 3513-3519.

204. Ser H-L, Yin W-F, Chan K-G, et al., Antioxidant and cytotoxic potentials of Streptomyces gilvigriseus MUSC 26T isolated from mangrove soil in Malaysia. Prog Microb Mol Biol 2018; 1(1).

205. Ser H-L, Chan K-G, Tan W-S, et al., Complete genome of mangrove-derived anti-MRSA streptomycete, Streptomyces pluripotens MUSC 135T. Prog Microb Mol Biol 2018; 1(1).

206. Eccleston GP, Brooks PR, and Kurtboke DI, The occurrence of bioactive micromonosporae in aquatic habitats of the Sunshine Coast in Australia. Mar Drugs 2008; 6(2): 243-61.

207. Han Y, Yang B, Zhang F, et al., Characterization of antifunga chitinase from marine Streptomyces sp. DA11 associated with South China Sea sponge Craniella australiensis. Mar Biotechnol (NY) 2009; 11(1): 132-40.

208. Schmidt E, Obraztsova A, Davidson S, et al., Identification of the antifungal peptide-containing symbiont of the marine sponge Theonella swinhoei as a novel $\delta$-proteobacterium, "Candidatus Entotheonella palauensis". Mar Biol 2000; 136(6): 969-977.

209. Selvin J, Joseph S, Asha K, et al., Antibacterial potential of antagonistic Streptomyces sp. isolated from marine sponge Dendrilla nigra. FEMS Microbiol Ecol 2004; 50(2): 117-122.

210. Pimentel-Elardo SM, Kozytska S, Bugni TS, et al., Anti-parasitic compounds from Streptomyces sp. strains isolated from Mediterranean sponges. Mar Drugs 2010; 8(2): 373-80.

211. Nithyanand P, Manju S, and Karutha Pandian S, Phylogenetic characterization of culturable actinomycetes associated with the mucus of the coral Acropora digitifera from Gulf of Mannar. FEMS Microbiol Lett 2011; 314(2): 112-8.

212. Zhang XY, He F, Wang GH, et al., Diversity and antibacterial activity of culturable actinobacteria isolated from five species of the South China Sea gorgonian corals. World J Microbiol Biotechnol 2013; 29(6): 1107-16.

213. Li J, Dong JD, Yang J, et al., Detection of polyketide synthase and nonribosomal peptide synthetase biosynthetic genes from antimicrobial coral-associated actinomycetes. Antonie Van Leeuwenhoek 2014; 106(4): 623-35.

214. Tanaka H, Koyama Y, Awaya J, et al., Nanaomycins, new antibiotics produced by a strain of Streptomyces. I. Taxonomy, isolation, characterization and biological properties. J Antibiot (Tokyo) 1975; 28(11): 860-7.

215. Hollants J, Leliaert F, De Clerck O et al., What we can learn from sushi: a review on seaweed-bacterial associations. FEMS Microbiol Ecol 2013; 83(1): 1-16.

216. Ser HL, Ab Mutalib NS, Yin WF, et al., Evaluation of antioxidative and cytotoxic activities of Streptomyces pluripotens MUSC 137 isolatede from mangrove soil in Malaysia. Front Microbiol 2015

217. Tan LT-H, Chan K-G, Lee L-H, et al., Streptomyces bacteria as potential probiotics in aquaculture. Front Microbiol 2016; 7: 79

218. Ahmed E and Holmstrom SJ, Siderophores in environmental research: roles and applications. Microb Biotechnol 2014; 7(3): 196-208.

219. Banin E, Vasil ML, and Greenberg EP, Iron and Pseudomonas aeruginosa biofilm formation. Proc Natl Acad Sci U S A 2005 102(31): 11076-11081.

220. Berlutti F, Morea C, Battistoni A, et al., Iron availability influences aggregation, biofilm, adhesion and invasion of Pseudomonas aeruginosa and Burkholderia cenocepacia. Int J Immunopathol Pharmacol 2005; 18(4): 661-670.

221. Mey AR, Craig SA, and Payne SM, Characterization of Vibrio cholerae RyhB: the RyhB regulon and role of ryhB in biofilm formation. Infect Immun 2005; 73(9): 5706-5719. 